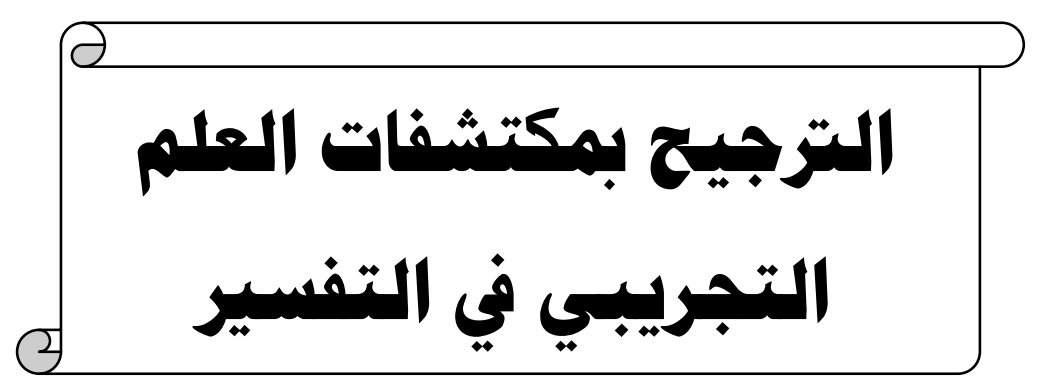

دكتور/ عبد السلام بن صالح بن سليسمان الجار الله

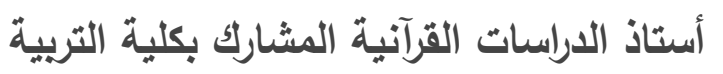

جامعة الملك سعود بالرياض - المملكة العربية السعودية 
الترجيح بمكتثفات العلم التجريبي في التفسير د/عبد السلام بن صالح بن سليمان الجار الله

مجلة كلية أصول الاين بأسيوط ،العدد الرابع الثلاثون 175 ب م م 175 


\section{هلنص البحث}

الأدلة والمرجحات التي يلجأ إليها المفسر في الترجيح بين الأقوال

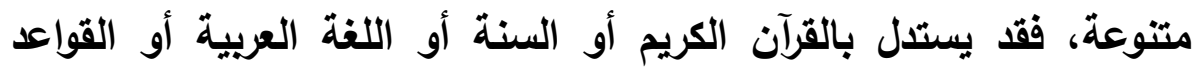

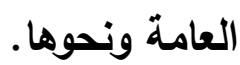

ومن المرجحات التي يلجأ إليها بعض الناس توظيف مكتثفات العلم التجريبي قرينةً ترجيحيةً بين أقوال المفسرين المختلفة في معاني الآيات، وتأتي مشكلة البحث من قيام بعض الناس - بدافع الحماس - باستخدام

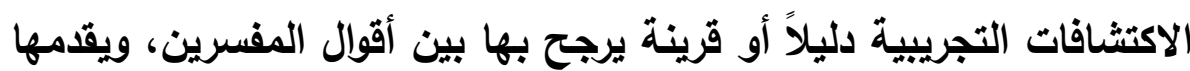

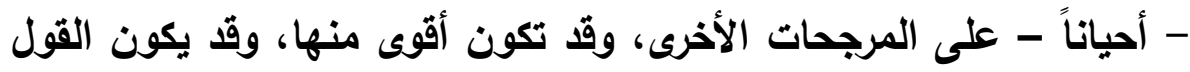
الذي يرجحه بالمكتشفات التجريبية ضعيفاً أو شاذاً.

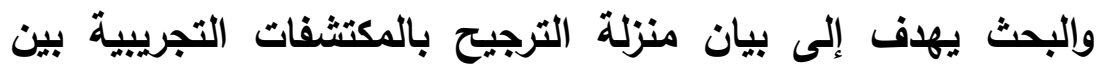

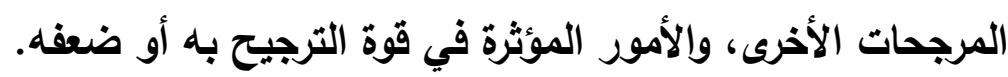
وقث تناول الباحث أريعة قضايا: - التفاوت بين المرجحات في التفسير.

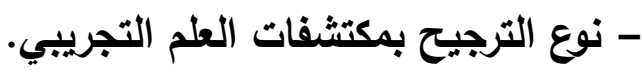
- الترجيح بمكتثفات العلم التجريبي عند المتقدمين. - الأمور المؤثرة في الترجيح بمكتثفات العلم التجريبي. - بعض صور الترجيح بمكتثفات العلم التجريبي المقبولة والمردودة.

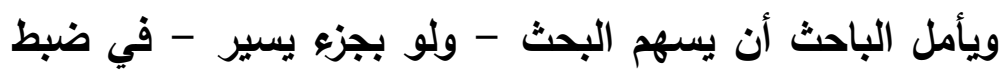
مسيرة الإعجاز العلمي وتفسير الكتاب العزيز بككتثفات العلم التجريبي. الكلمات المفتاحية: تفسير القرآن، قواعد الترجيح، إعجاز القرآن، الإعجاز العلمي، التفسير العلمي، العلم التجريبي. 


$$
\text { بسم الله الرحمن الرحيم }
$$

الحمد الله رب العالمين والصلاة والسلام على أشرف الأنبياء والمرسلين؛

$$
\begin{aligned}
& \text { أما بعد: } \\
& \text { نبينا محمد وعلى آله وصحبه أجمعين }
\end{aligned}
$$

مما ينبغي للمفسر حين تعدد الأقوال واختلاف الآراء حول معنى آية

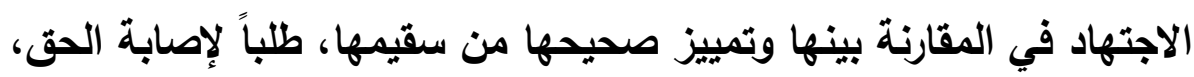

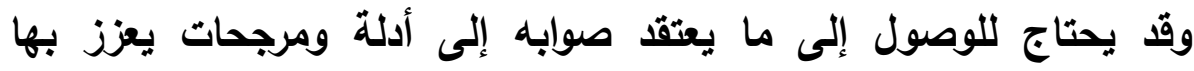

والأدلة والمرجحات التي يلجأ إليها المفسر في الترجيح بين الأقوال

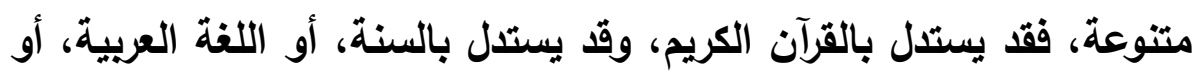
القواعد العامة ونحوها. ومما غُني به بعض المعاصرين في الترجيح بين معاني القرآن الكريم ما يتصل بالإعجاز العلمي والاكتثافات التجريبية الحديثة مما وقع في القئ القرآن

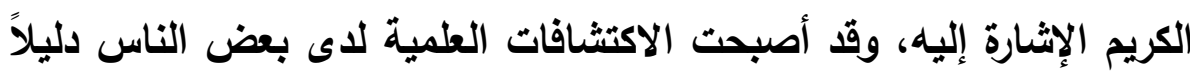
يُحتكم إليه في بيان صحة معنئً من المعاني أو ضعفه. وقد رغبت في دراسة هذه القضية؛ إذ لم أجد حسب عندي علمي من أفرد هذه فئه القضية بخصوصها في بحث مستقل (1)، ودعاني للحديث عنها الأمور الآتية: 1 - ارتباطها بكتاب الله تعالى وتفسيره.

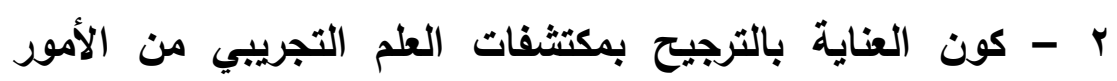

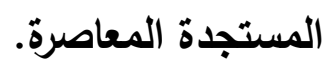

للاكتور صالح يحي صواب بحث بعنوان: أثر الاكثثافات العلمية في تفسير القرآن

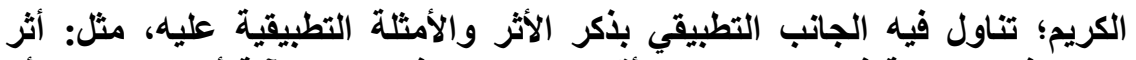

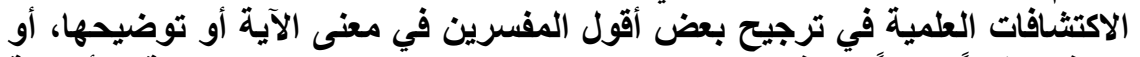

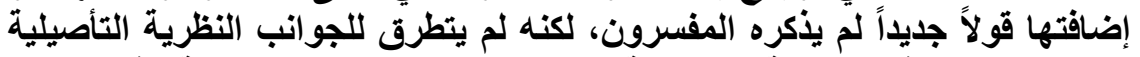

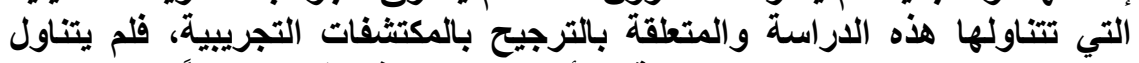

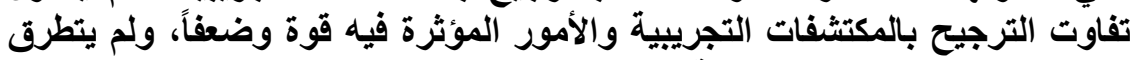
لنوع الترجيج بالمكتفات العلمية.

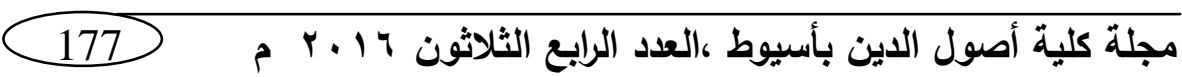


r - يدفع الحماس الثديد بعض المشتظلين بالإعجاز العلمي إلى تبني

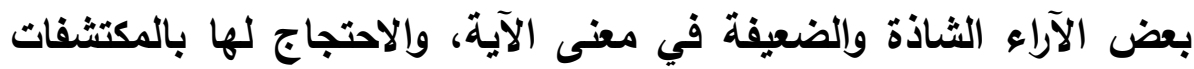

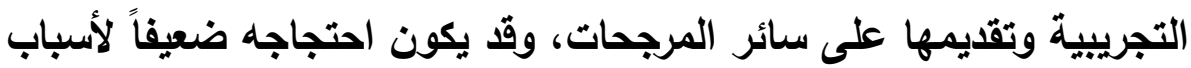
يرد ذكرها في البحث إن شاء الله تعالى.

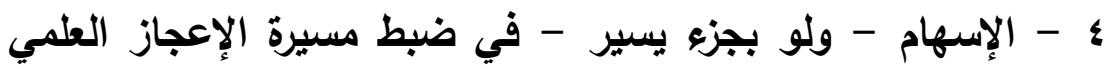
وتفسير الكتاب العزيز بالمكتشفات التجريبية. مشكلة البحث:

يستخدم بعض الناس الاكتثافات التجريبية دليلاً أو قرينة يرجح بها

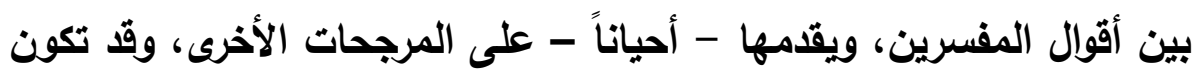

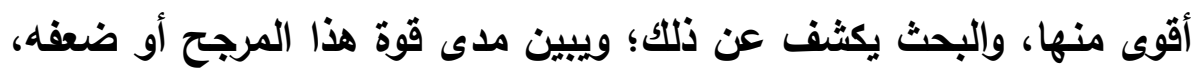
ومنزلته بين المرجحات. هاف البحث:

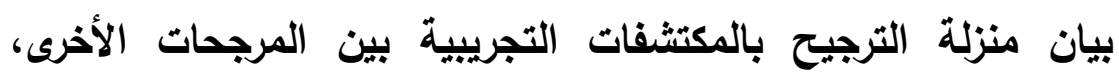
والأمور المؤثرة في قوة الترجيح به أو ضعفه.

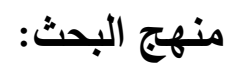
سأتبع المنهج الاستقرائي التحليلي حسب المباحث الآتية: المبحث الأول: التفاوت بين المرجحات في التفسير. المبحث الثاني: نوع الترجيح بمكتشفات العلم التجريبي.

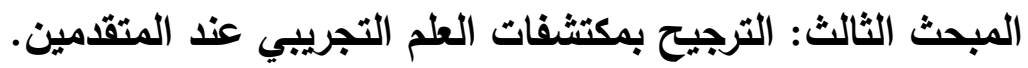

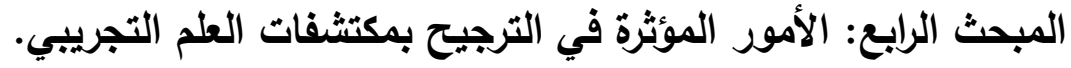
المبحث الخامس: من صور الترجيح بمكتشفات العلم التجريبي.

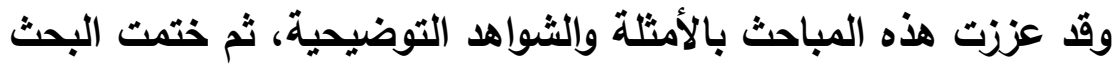

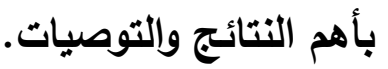
والله ولي التوفيق 


\section{المبحث الأول}

\section{التفاوت بين المرجمات في التفسير}

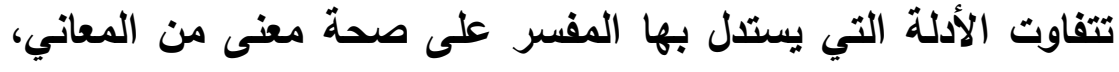
فبعضها أقوى من بعض، بل إن الاليل الواحد يتفاوت في نفسه، من حيث الآله

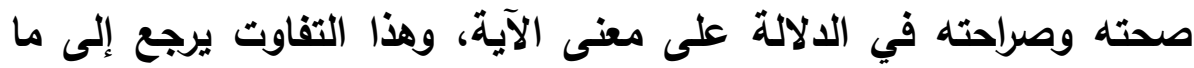

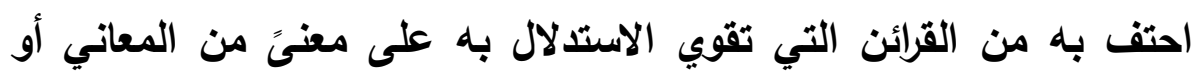

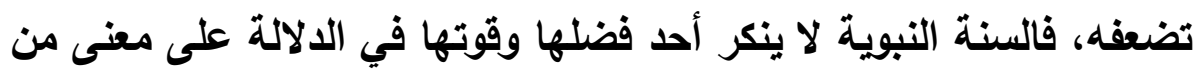

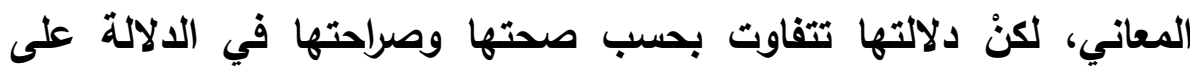
المعنى، فحين تكون صحيحة ونصاً في المعنى لا يجوز الالتفات إلى غيرها،

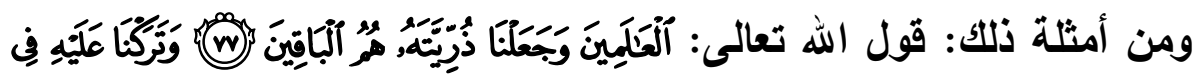

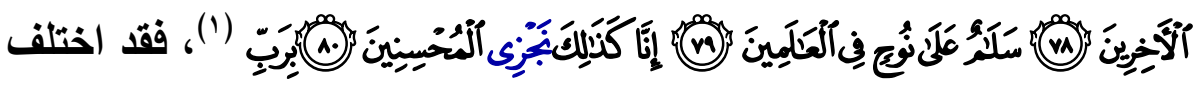
المفسرون في كيفية دخولهم الباب، والقول الذي بلولوه:

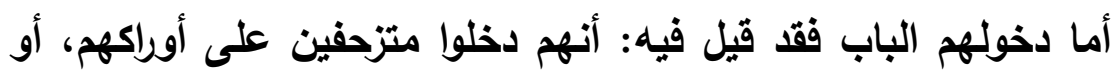

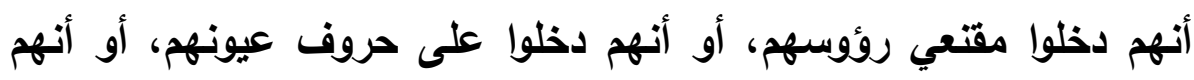

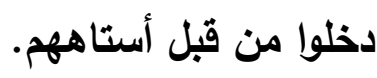

وأما القول الأي بدلوه فقيل: أنهم قالوا: حنطة حمراء فيها شعرة، أو

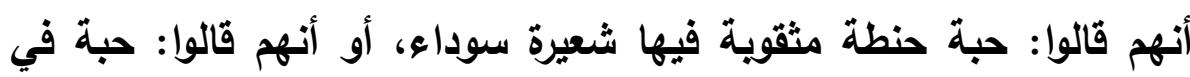

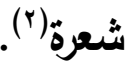
وقد فسر النبي

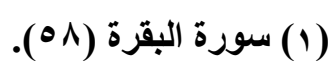

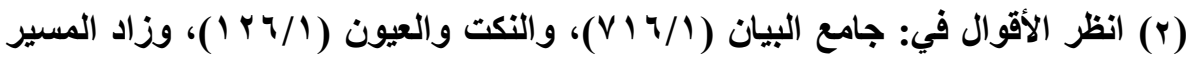

$$
\text { (^०/1) }
$$

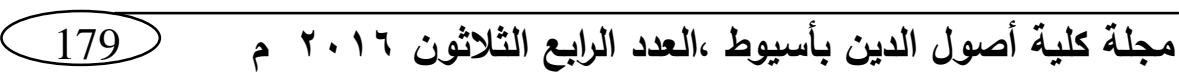


وقولوا: حطة، فرخلوا يزحفون من أستاههم، وقالوا: حبة في شعرة "((')

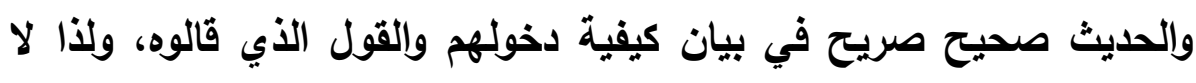
ينبغي الالتفات إلى غيره من الأقوال.

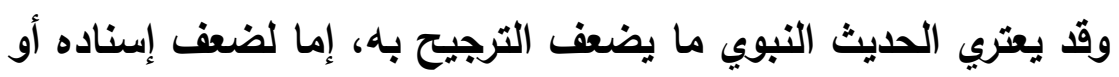

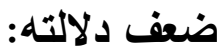

أما ضعف الإسناد فقد يكون الحديث نصاً في تفسير الآية، لكن لا

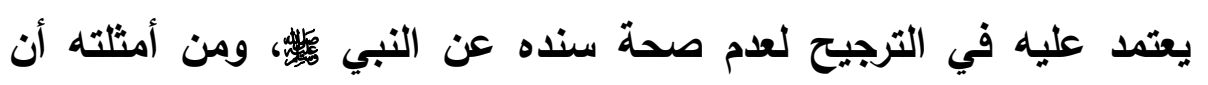

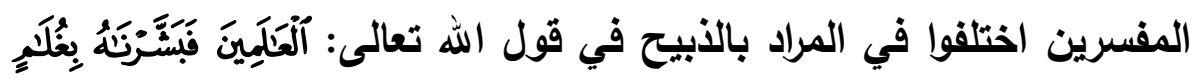

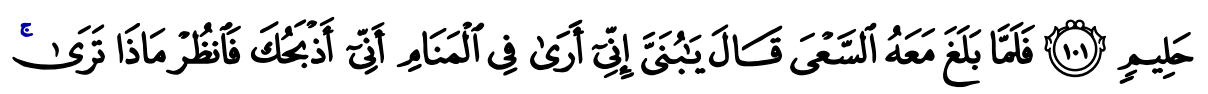

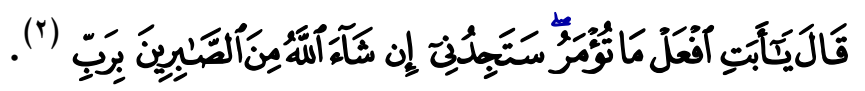

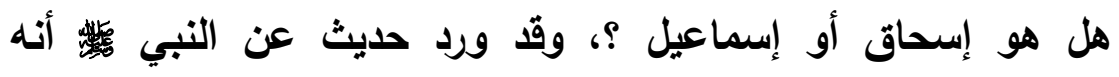

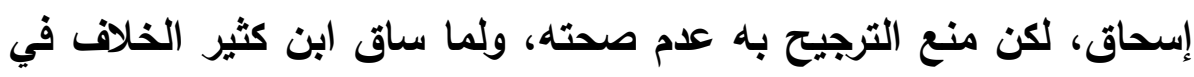
تعيين الذبيح، وذكر قول من قال: إنه إسحاق عقب بقوله: " وقد ورد في ذلتك

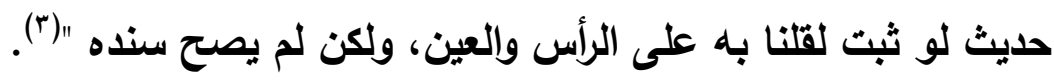

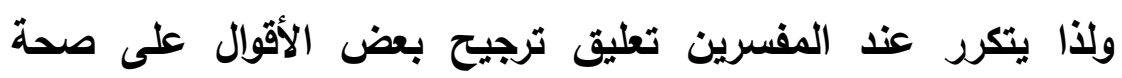

$$
\text { الحديث الوارد فيه(؛). ولن. }
$$

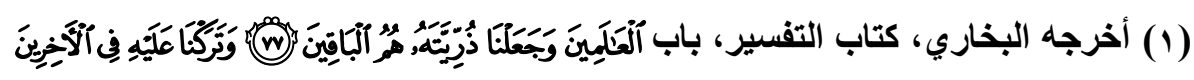

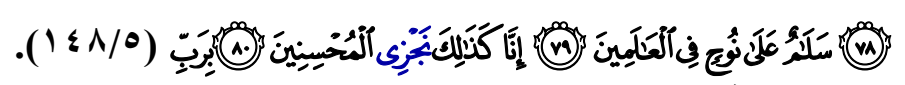

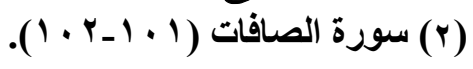

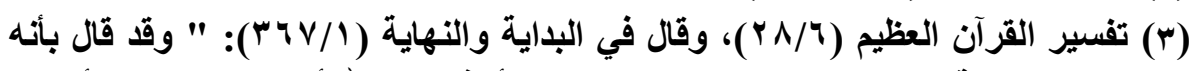

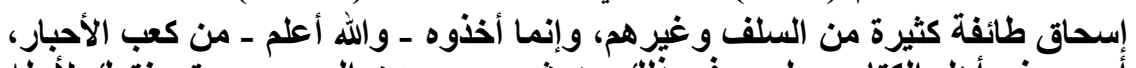

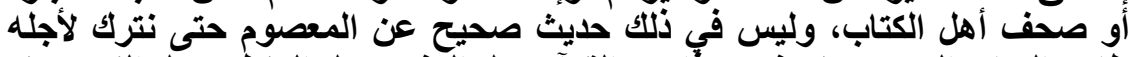
ظاهر الكتاب العزيز، ولا يفهم هذًا من القرآن، بل المفهوم بل المنطوق بل النص غند

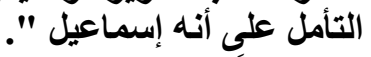

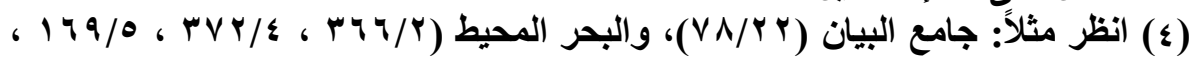

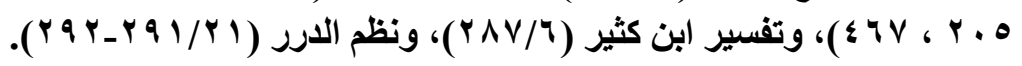

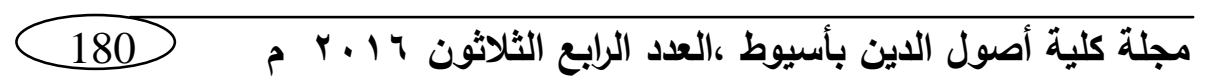


وأما ضعف دلالة الحديث على معنى الآية؛ فمن أمثلته أن المفسرين

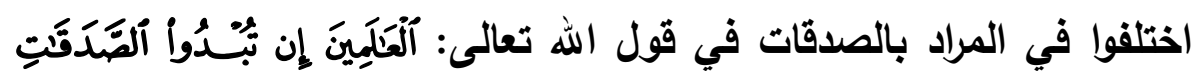

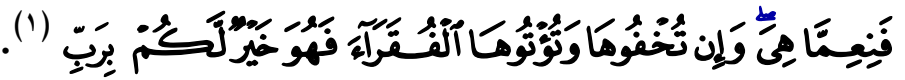

هل هي الصدقات المفروضة أو صدقات التطوع ؟؛ على قولين، وقد

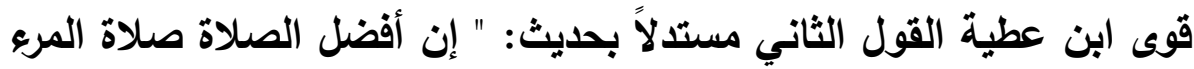

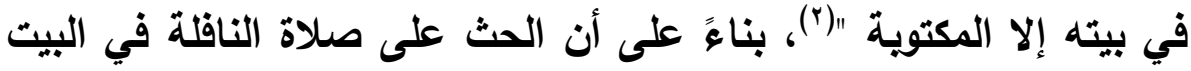

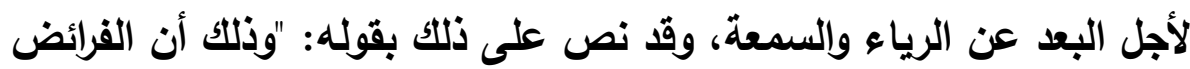

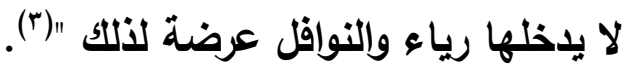

غير أن هذا الحديث في بيان فضيلة صلاة النافلة في في البيت، والآية في الصدقات، وأيضاً فالعلة في الحث على صلاة النافلة في البيت محتملة،

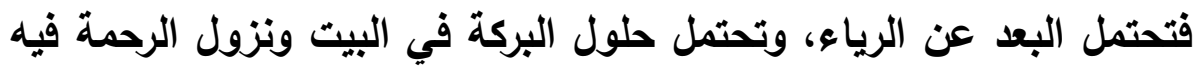

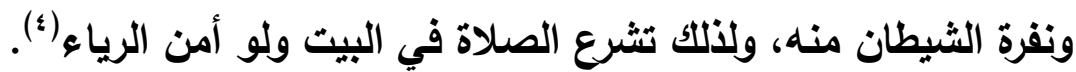

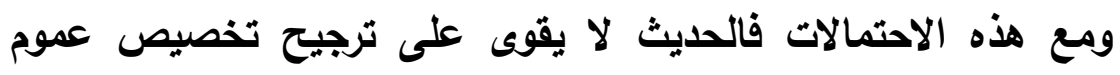
الآية بصدقات التطوع. قال ابن كثير: " الآية عامة في أن إخفاء الصدقة أفضل، سواء كانت

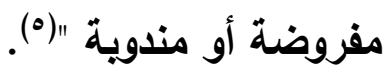

وتأمل التفاوت بين الترجيح بهذا الحديث والحديث السابق في تفسير

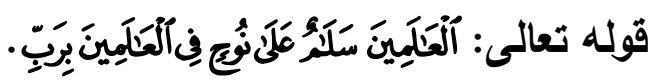

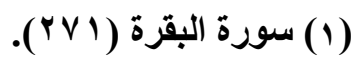

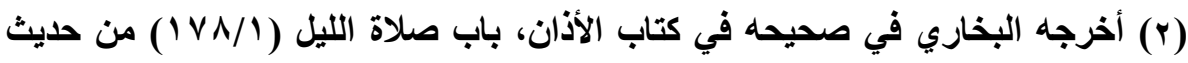

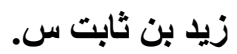

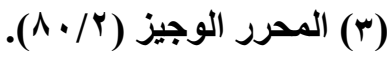

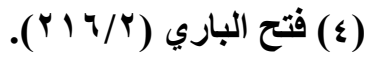

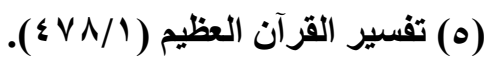


ويهذا يتبين أن المرجح الواحد يتفاوت الترجيح به قوة وضعفاً بحسب ما احتف به من قرائن.

وهذا التفاوت في الترجيح بالسنة بمعزل عن فضلها ومنزلتها مما لا جدال فيه، وإنما حصل التفاوت بمؤثرات أخرى. وهذه الأمور المذكورة في تفاوت الترجيح بالسنة تسري على الترجيح

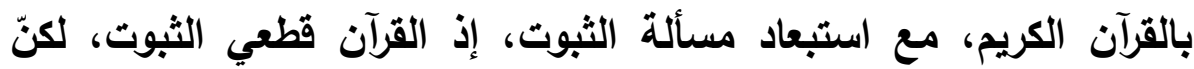

$$
\text { الترجيح به يتفاوت بتفاوت دلالته. }
$$

وقد ذكر الأصوليون التفاوت بين دلالات النصوص، وقدموا بعضها على بلى

بعض، فقدما دلالة النص على دلالة الظاهر ، ودلالة الإيماء (1).

وقدموا ما دل بمفهوم الموافقة على ما دل بمفهوم المخالقة (ץ).

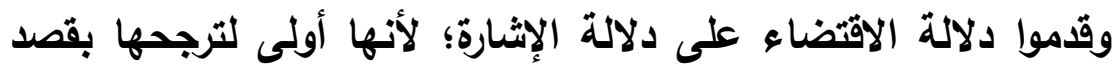
المتكلم لها بخلاف دلالة الإثارة(־).

(1) انظر: البحر المحيط للزركشي (7/7 Y Y ) ، والنص هو ما يفيد بنفسه من غير احتمال

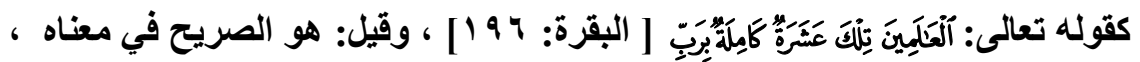

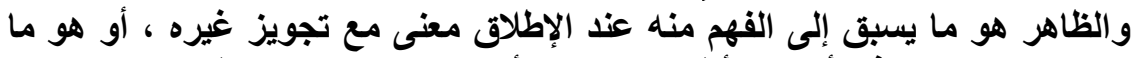

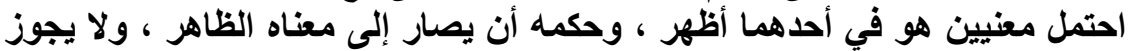

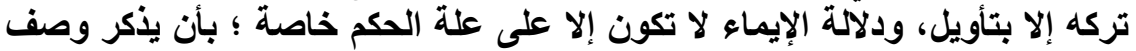

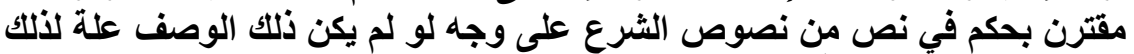

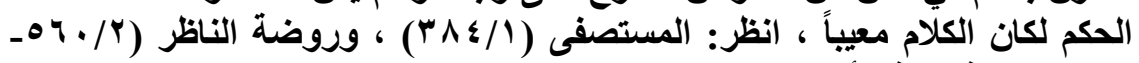

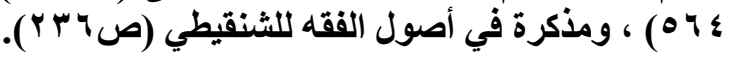

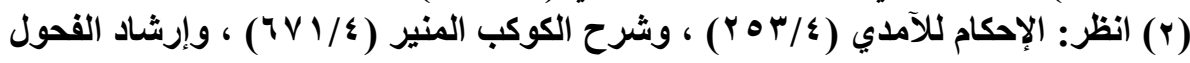

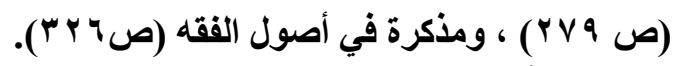

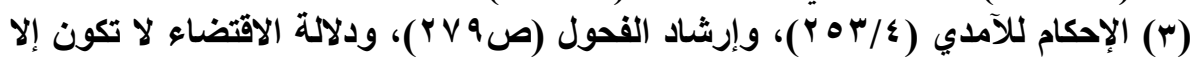

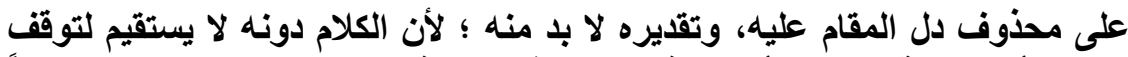

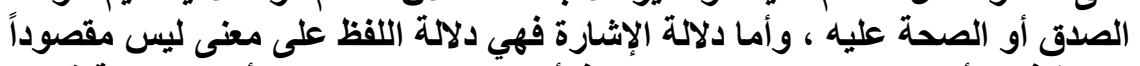

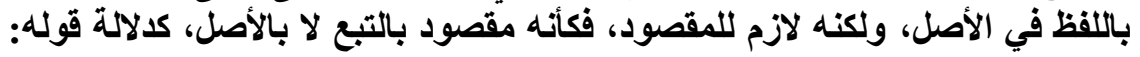

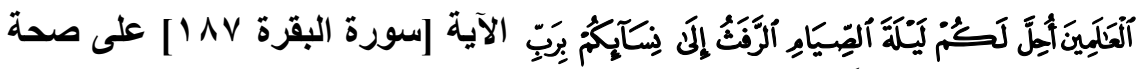

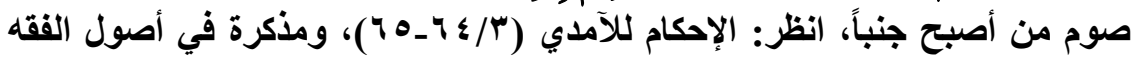

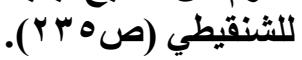




$$
\text { وقدموا دلالة المطابقة على دلالة الالتزام لأنها أضبط' (1). }
$$

وجاء في كلام العلماء ما يؤكد تفاوت المرجحات من خلال حليثهر عن

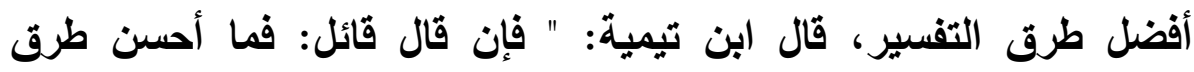

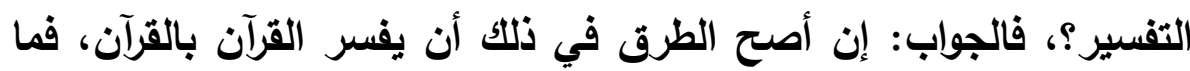

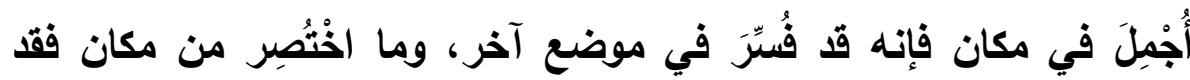

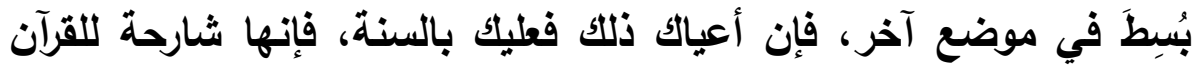
وموضحة له "(؟). وهذا مشروط بصحة التفسير، لأنه قد يعتري التفسير ما يضعفه، وقد ذكر العلماء ضوابط وشروطا لتفسير القرآن الكريم. وإذا كان هذا التفاوت يقع في المرجحات من الكتاب والسنة فوقوطعه في غيرهما من باب أولى كالترجيح باللغة العربية ونحوها.

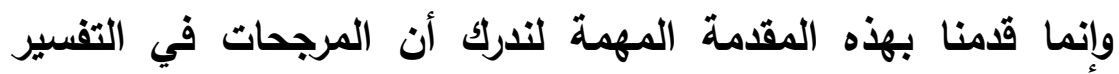

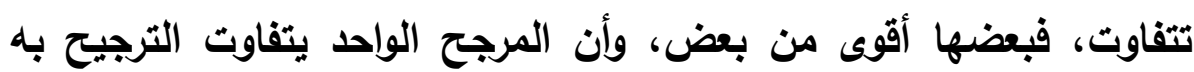
بحسب ما احتف به من القرائن. 


\section{المبـث الثاني}

\section{نوع الترجيح بمكتشفات العلم التجريبي}

معرفة نوع الترجيح بالمكتثفات التجريبية من الأهمية بمكان؛ فهو يبين لنا منزلته ودرجته بين المرجحات في التفسير. وعند التأمل في هذا النوع من المرجحات يظهر لنا دخوله ضئه ضمن الأدلة العقلية والتفسير بالرأي.

وتطبيقات التفسير التي تندرج تحت المكتشفات التجريبية مشتركة بين الاستدلال بالعقل والاستدلال بالحس والمشاهدة؛ ذلك أن العلوم التجريبية

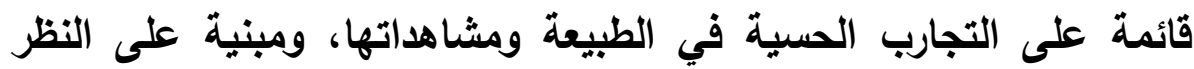
والتأمل في مخلوقات الله ، ثم استخلاص القوانين والوصول إلى الحقائق(')، وقد ضرب الغزالي لذلك مثلاً بالشمس فمعرفة كونها أكبر من الأرض إنما يكون بأدلة هندسية تبنى على مقدمات حسية"(r). والاستدلال بالحس والمشاهدة له أصل في الثريعة وأدلته كثيرة: فقد جاء في آيات كثيرة الاستدلال بالواقع والحس والمشاهلة على البعث والنشور، وشواهده من القرآن الكريم أكثر من أن تحصى، قال الله

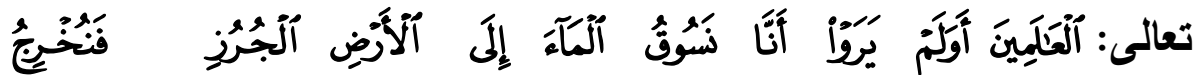

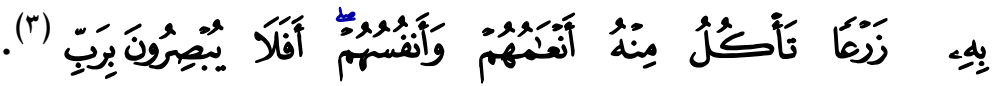

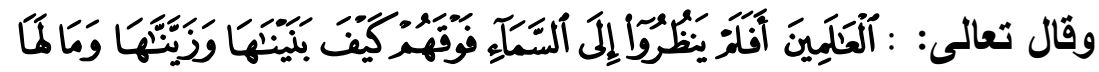

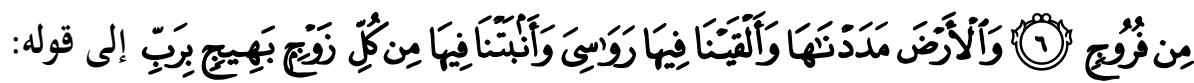

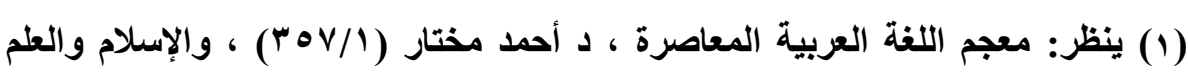

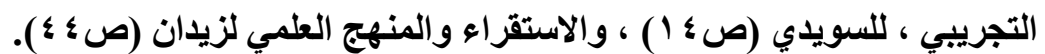




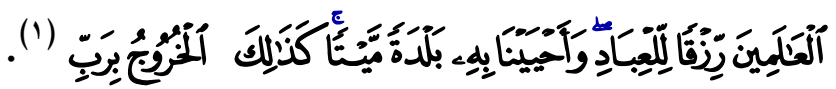
وفي جانب آخر حثت آيات كثيرة على النظر في ملكوت السموات

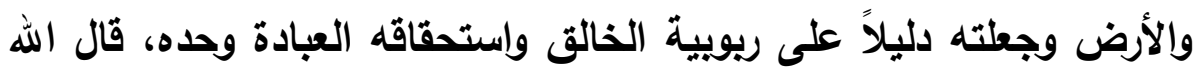

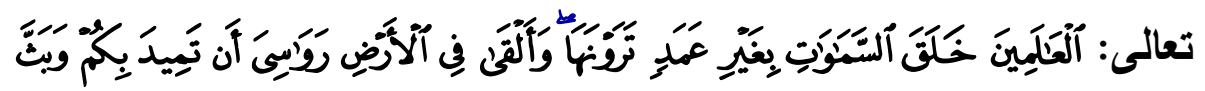

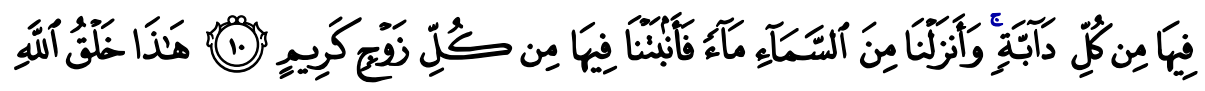

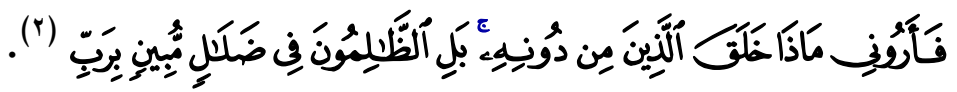

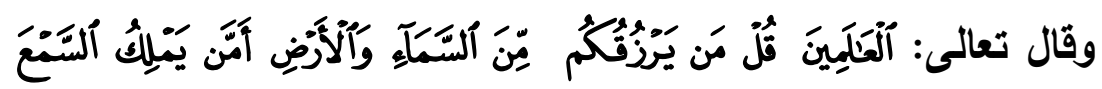

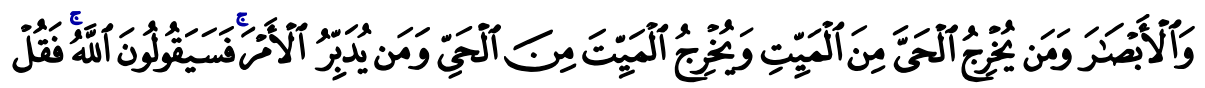

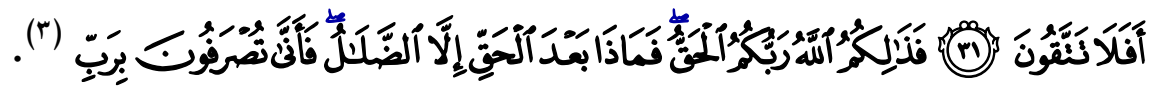

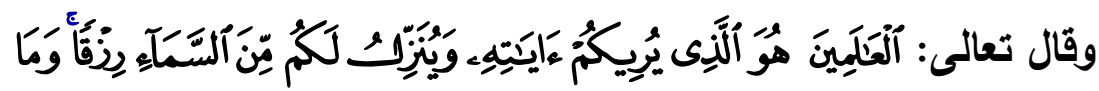

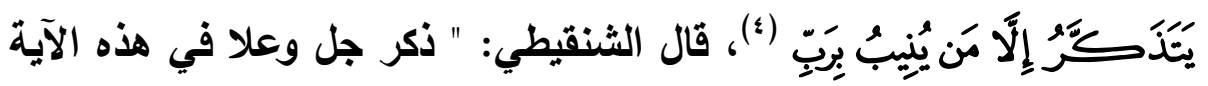

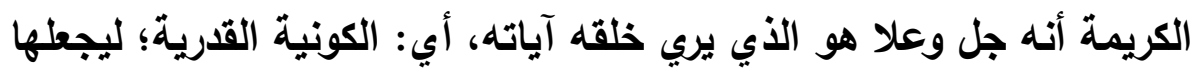
علامات لهم على ريوييته، واستحقاقه العبادة وحده، ومن تلك الآيات الليل

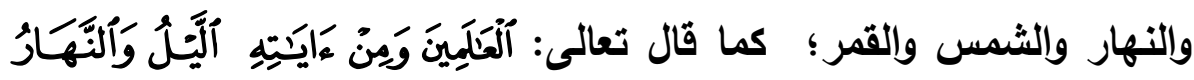

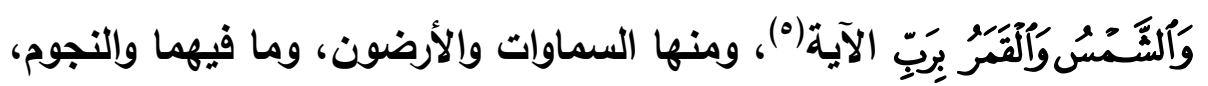

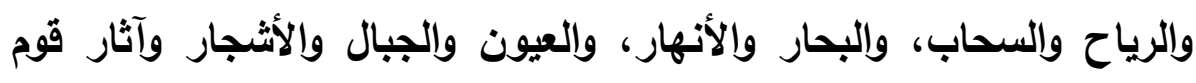

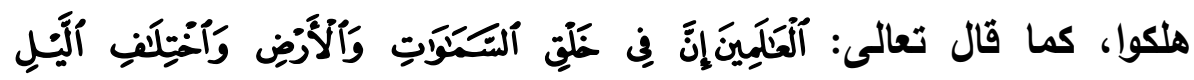

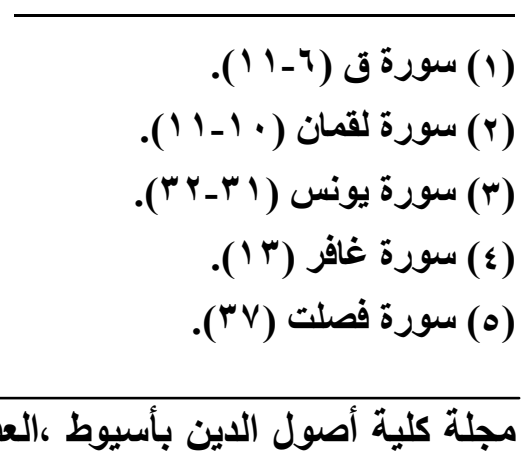

مجلة كلية أصول الاين بأسيوط ،العدد الرابع الثلاثون 185 ب م م 185 


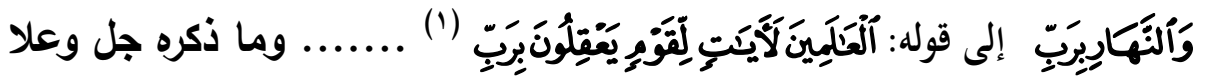

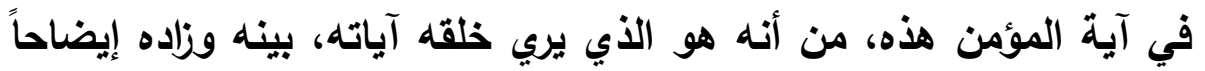

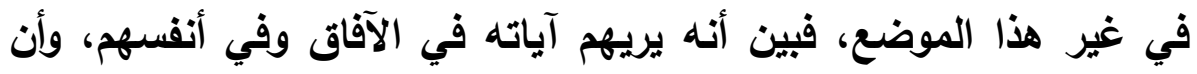

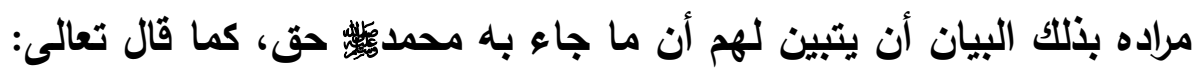

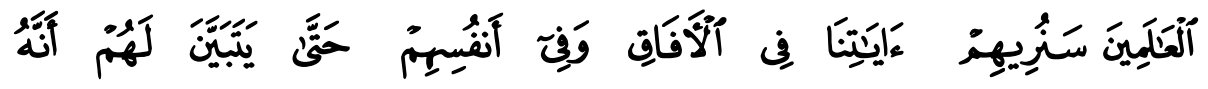

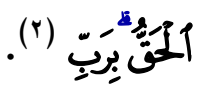
والآفاق جمع أفق وهو الناحية، والله جل وعلا قد بين من غرائب صنعه

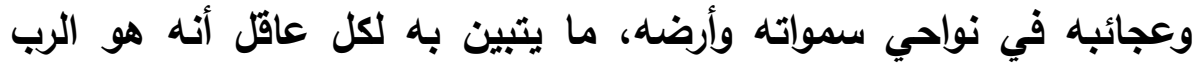

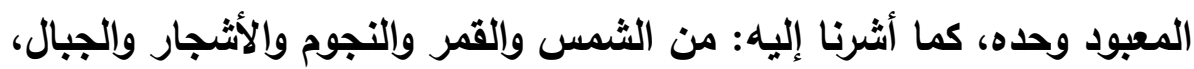

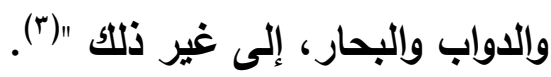
وهذا الأخير الذي ذكره الثنقيطي هو المتعلق بالمكتشفات التجريبية

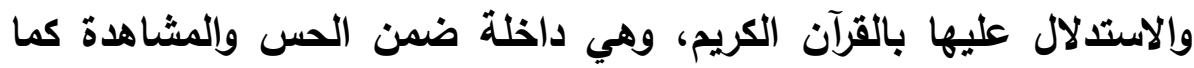
سيأتي تفصيله. وقد ذكر شيخ الإسلام ابن تيمية دليل الحس إضافة إلى دليل العقل والنقل ضمن المدارك الثلاثة التي قد يحصل للثخص بها بها علم يقطع به، وأن إنه العلم الحاصل بها قـ يكون ضرورياً في حق بعض الناس (4).

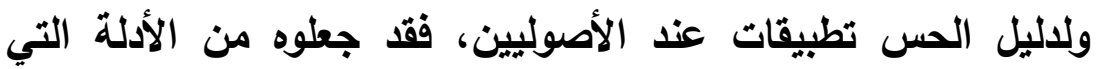

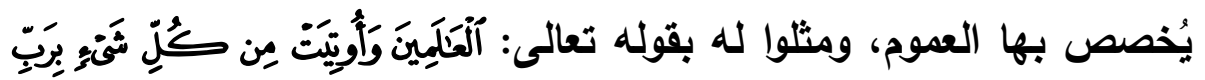

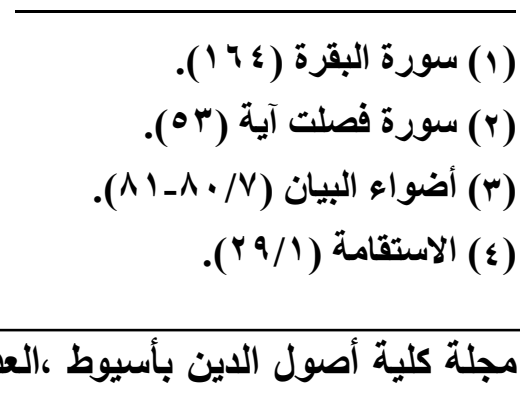

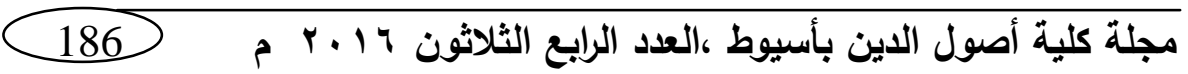


(1)، قالوا: وما كان في يد سليمان لم يكن في يدها، وهو شيء، وقوله:

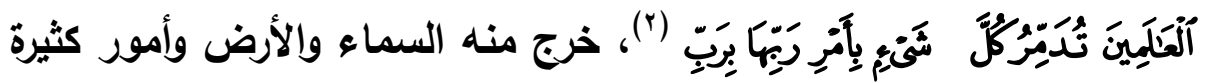

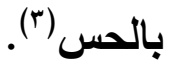

والاستدلال بالواقع والحس والمشاهدة له مدخل في فهم الكتاب العزيز وتفسيره، وقد غُني به المفسرون عند بيانهم معاني القرآن الكريم، واستخدمه السلف ومن بعدهم في سبر الأقوال التفسيرية ونقدها، ومن أمثلته: قول الله

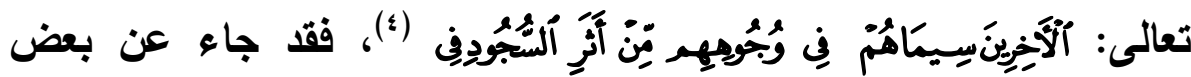

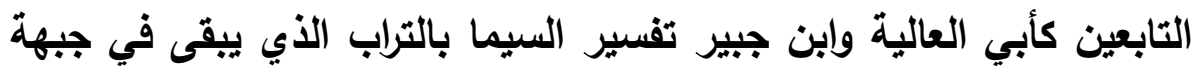
المريء بعد السجود (०). وقد يظن بعض الناس أن المراد بالسيما ما يرى في جباه بعض الناس

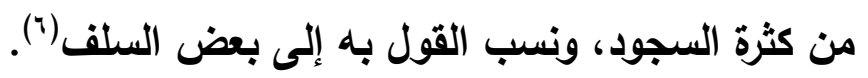

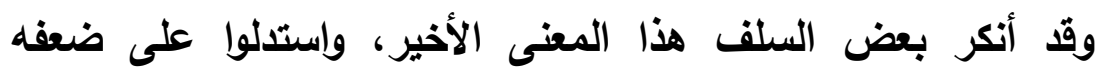

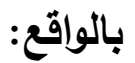
فقد سأل منصور مجاهداً عن هذه الآية، فقال: هو الخشوع، فقال له

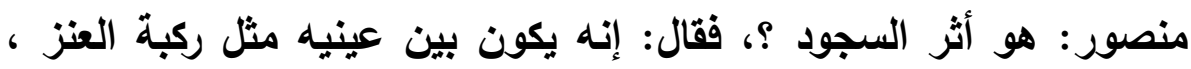
وهو كما شاء الله (V). وفي رواية أخرى أن منصوراً قال له: ما كنت أراه إلا هذا الأثر في

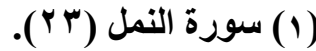

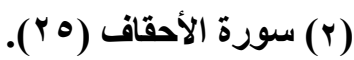

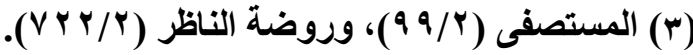

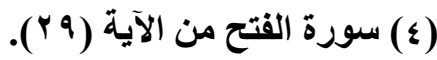

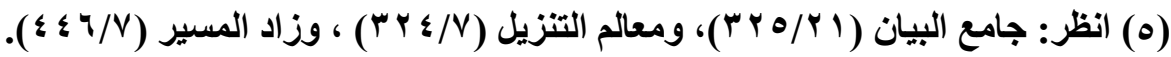

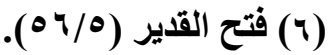

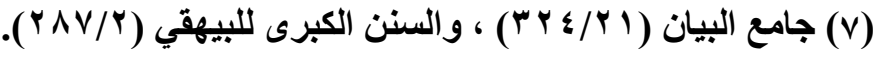

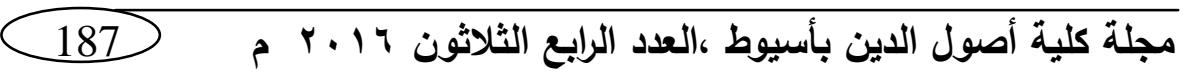


الوجه ، فقال: ريما كان بين عيني من هو أقسى قلباً من فرعون (1). وجاء رجل إلى السائب بن يزيد وفي وجهه أثر السجود، فقال: لقد هـ

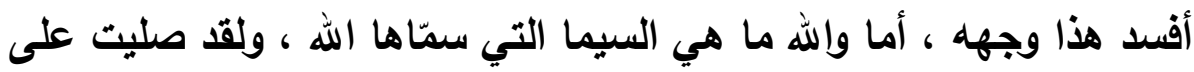

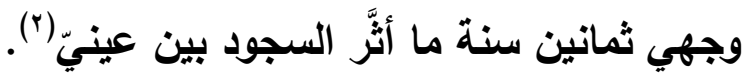

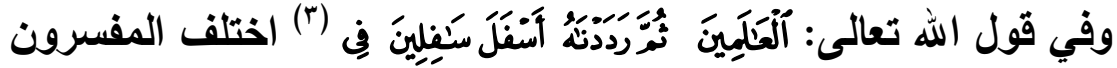
المفسرون في المراد على بأسفل سافلين على قولين: الأول: أن المراد الهرم وأربل العمر.

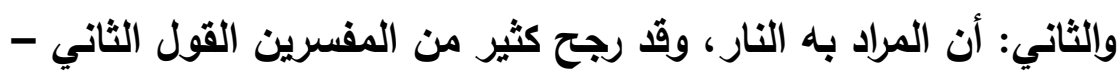
وهو الصحيح - واستبعدوا القول الأول، وقد ذكر ابن القيم عشرة أوجه لاستبعاده؛ الثامن منها: " أن أرياب القول الأول مضطرون إلى مخالفة

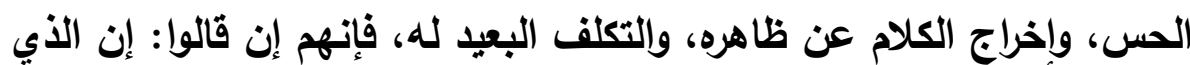

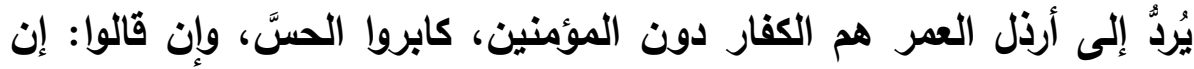

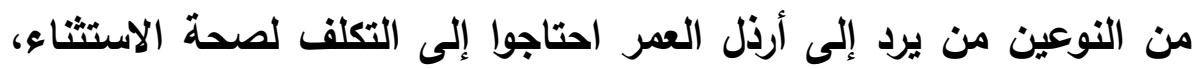

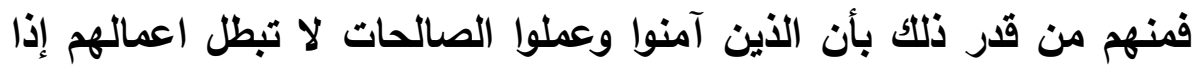

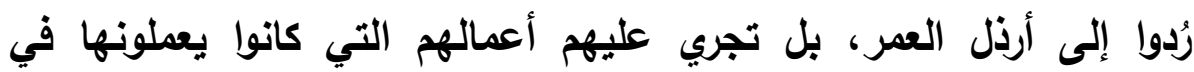

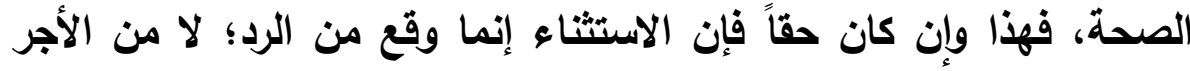

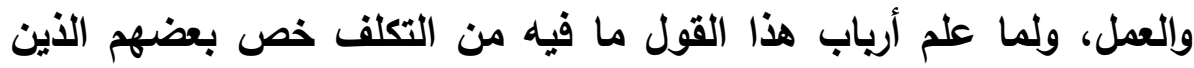

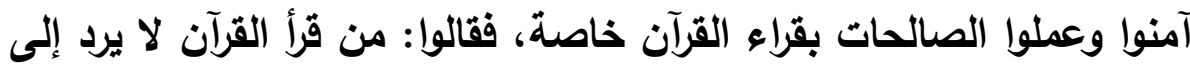

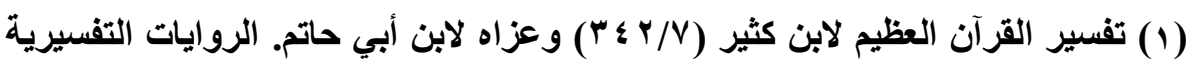

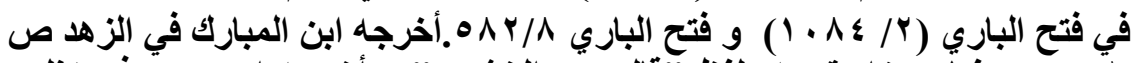

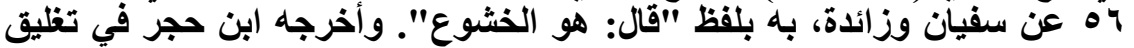

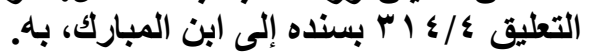

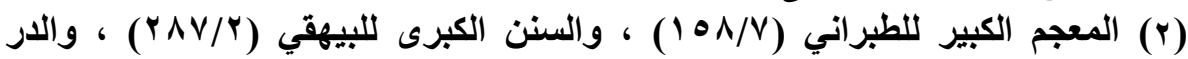

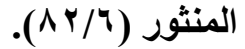

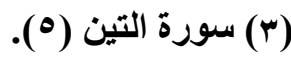

مجلة كلية أصول الدين بأسيوط ،العدد الرابع الثلاثون 19 
أرذل العمر، وهذا ضعيف من وجهين: أحدهما: أن الاستثناء عام في

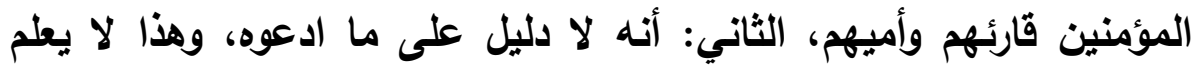

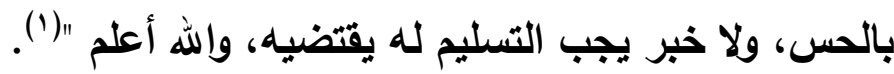
ومما يشهر لعلاقة المكتشفات التجريبية والإعجاز العلمي بالحس والمشاهدة أننا نجد المفسرين يريطون الآيات التي تدخل ضمن مباحث الإعجاز العلمي بالحس والمشاهدة: قال ابن القيم: " وقد أخبر سبحانها أنه بسط السحاب في السماء بقاء بقوله:

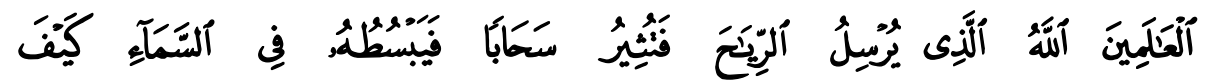

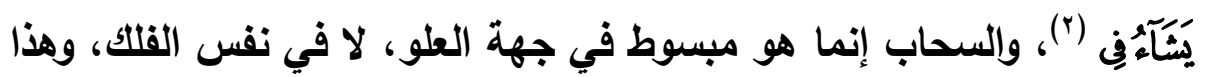
معلوم بالحس، فلا يلتفت إلى غيره "(").

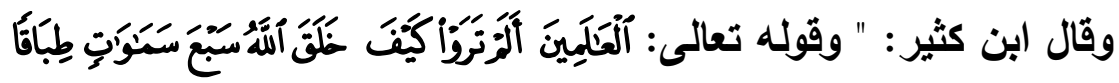

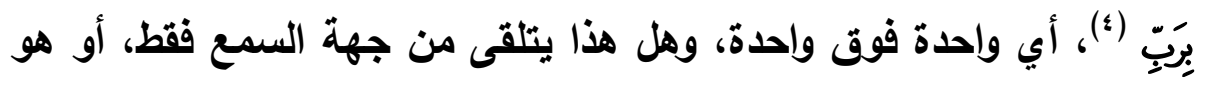
من الأمور المدركة بالحس مما علم من التسيير والكسوفات؟، فإن الكواكب

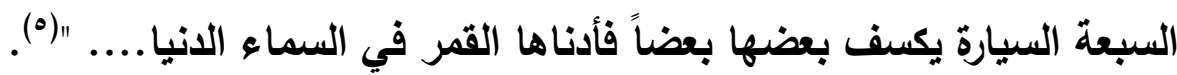

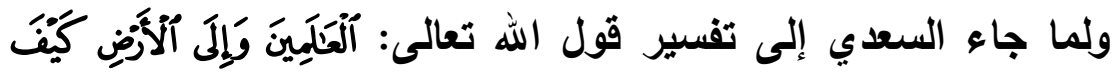

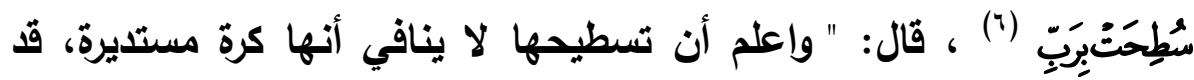
أحاطت الأفلاك فيها من جميع جوانبها، كما دل على ذلك النقل والعقل

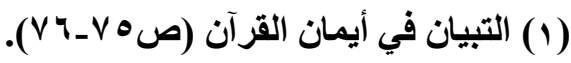

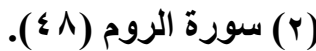

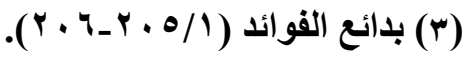

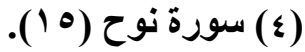

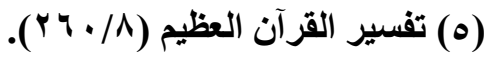

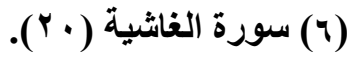

$$
\begin{aligned}
& \text { مجلة كلية أصول الدين بأسيوط ،العدد الرابع الثلاثون } 19
\end{aligned}
$$


والحس والمشاهدة، كما هو مذكور معروف عند أكثر الناس، خصوصاً في

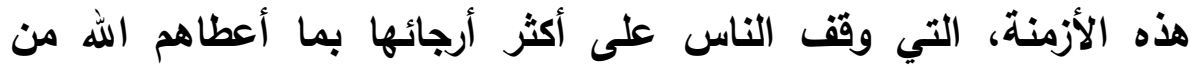

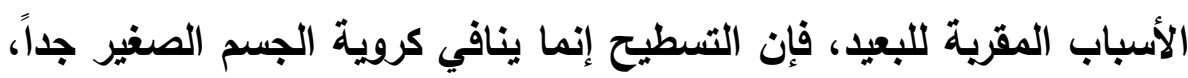

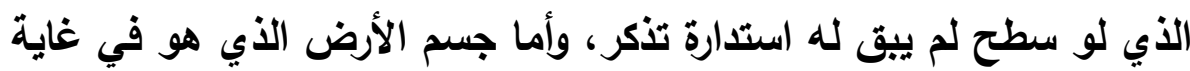

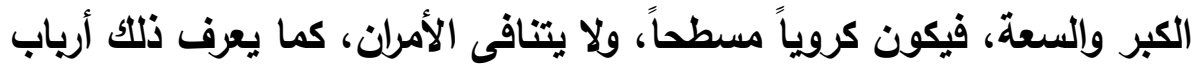

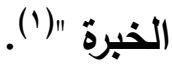

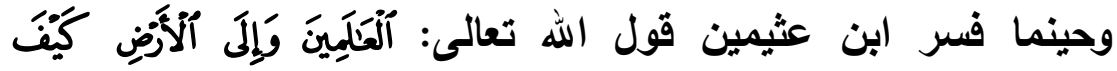

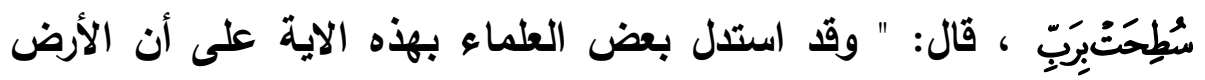

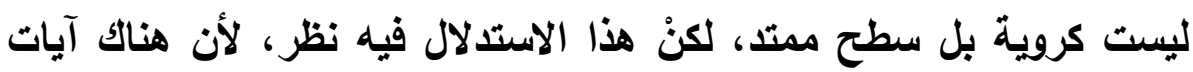

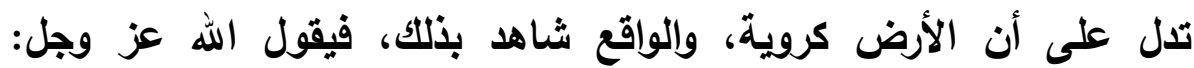

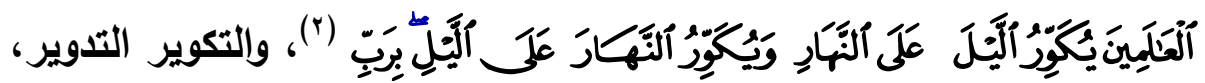

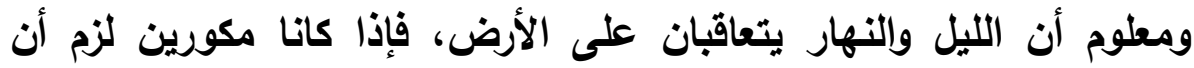
تكون الأرض مكورة "(؟). ومع ظهور العلاقة بين المكتثفات التجريبية ويين الحس والمشاهدة، وكون الحس كما تقدم مصدر مهم من مصادر المعرفة إلا أنه يتفاوت؛ ويخاصة في العلوم التجريبية الاقيقة، وهو ما سنتحدث عنه بالتفصيل في

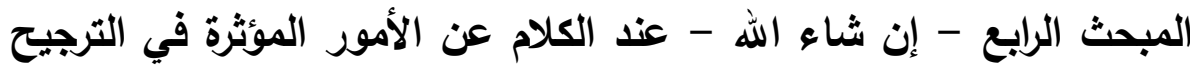

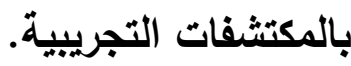

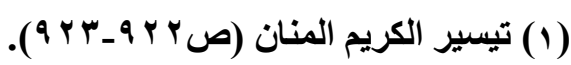

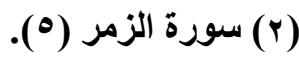

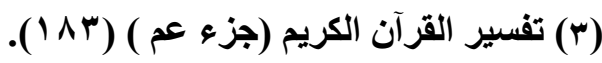

$$
\begin{aligned}
& \text { مجلة كلية أصول الدين بأسيوط ،العدد الرابع الثلاثون } 190 \text { ب م م م } 190
\end{aligned}
$$




\section{المبحث الثالث}

\section{الترجيح بمكتشفات العلم التجريبي عند المتقدهين}

يشترك المعاصرون - من حيث الأصل - مع المتقدمين في البحوث التجريبية بلاليل الاتفاق بينهم في البحوث التجريبية مما يتعلق بالسماء

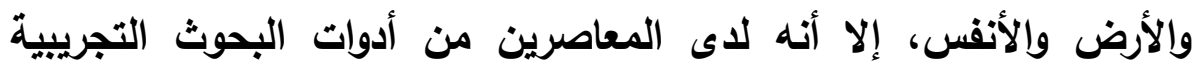
ومخترعاتها التي تساعدهم على مزيد من الاكتثافات ما ليس عند المتقدمين

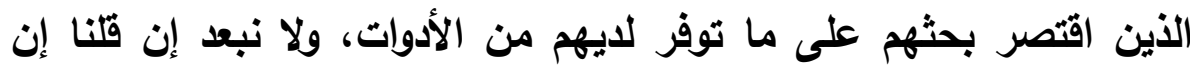

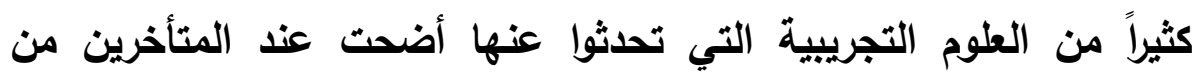

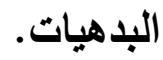

ويناء على هذا فقد قرر بعض العلماء المتقدمين التفسير العلمي من حيث المبدأ، وممن قرره الغزالبي والسيوطي، فقد قررا اشتمال القرآن الكريم على العلوم الكونية والطبيعية ودلالته عليها بطريق الإشارة؛ مستدلين بالآيات

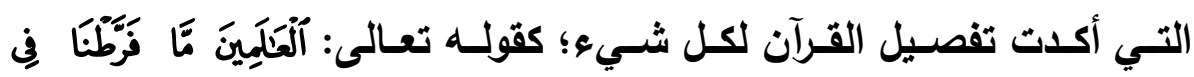

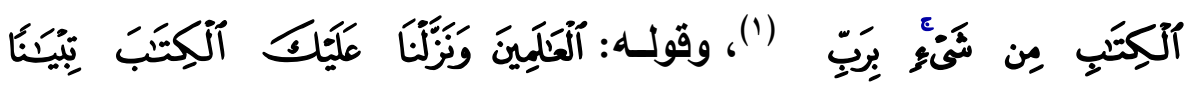

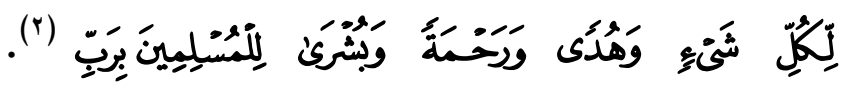

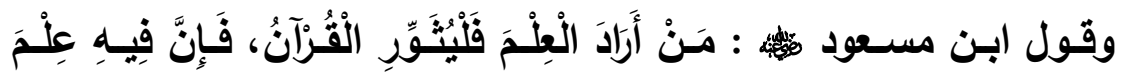

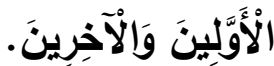

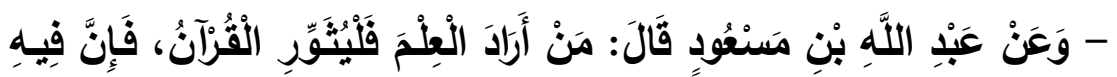

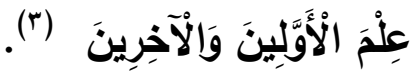

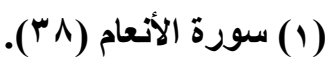

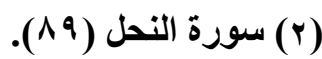

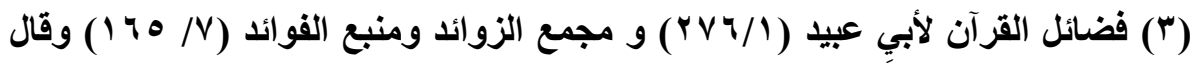

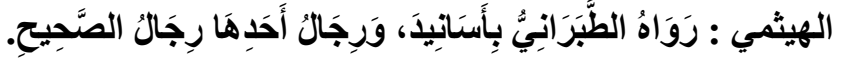

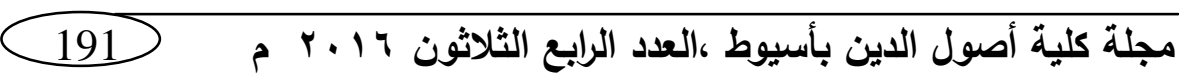


يقول الغزالي: " ظهر لنا بالبصيرة الواضحة التي لا يُتمارى فيها أن في

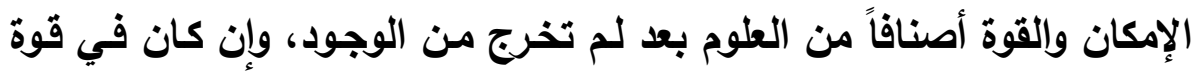

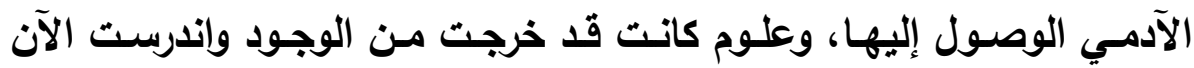

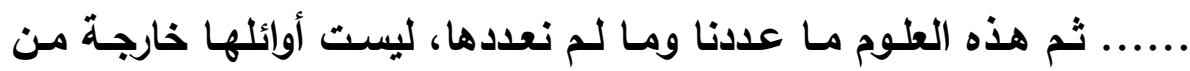

القرآن، فإن جميعها مغترفة من بحر واحد من بحار معرفة الله تعالى "( (1).

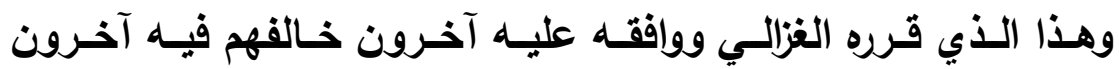

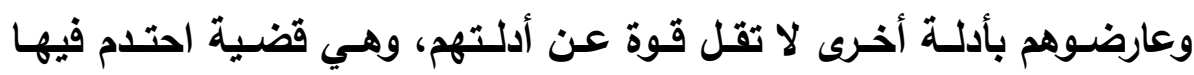
الخلاف وتثثب، وطال فيها الجدل قديماً وحديثًاً().

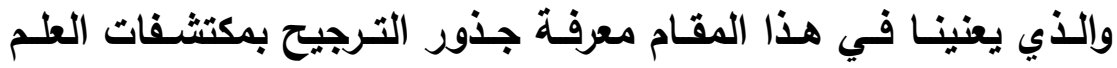

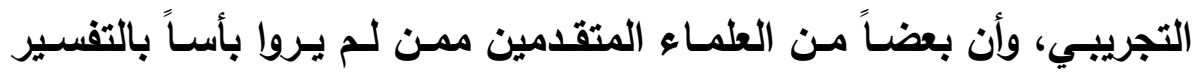

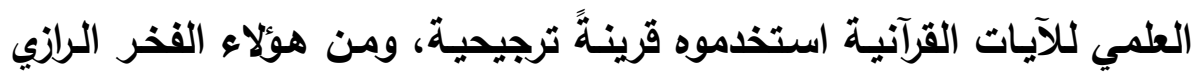
في مواطن من تفسيره:

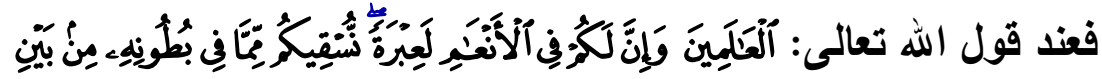

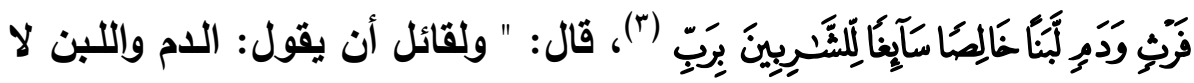

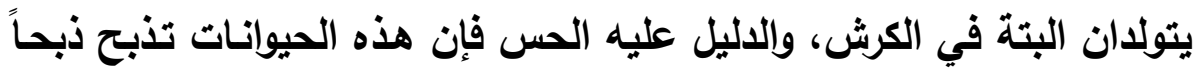

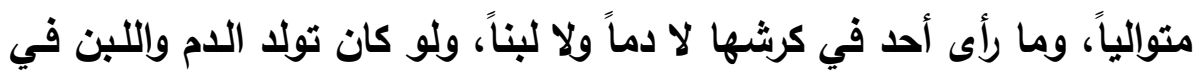

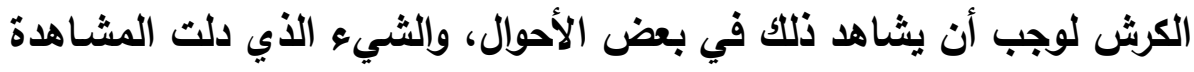

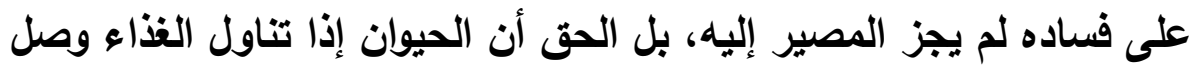

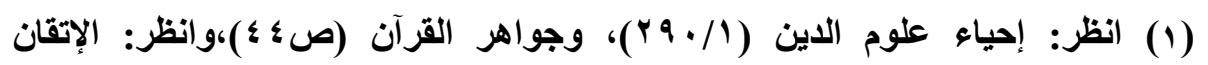

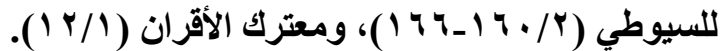

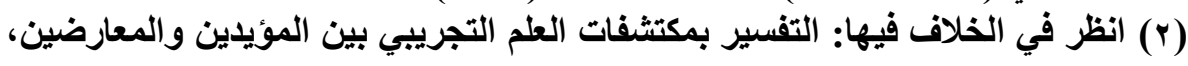

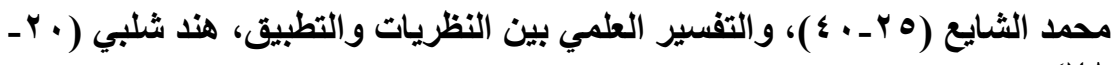


ذللك العلف إلى معدته إن كان إنسانا، وإلى كرشه إن كان من الأنعام وغيرها،

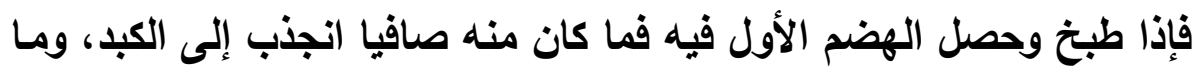

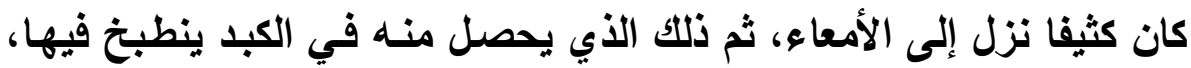

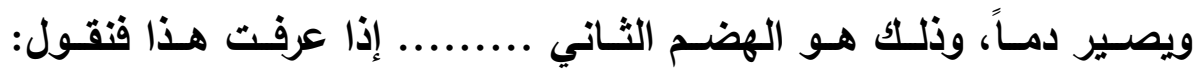

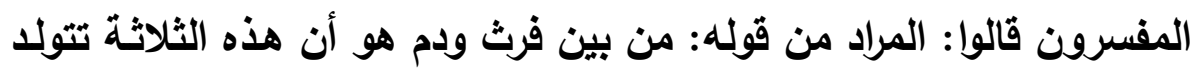

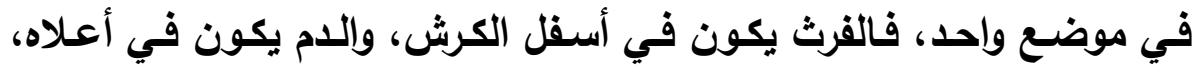

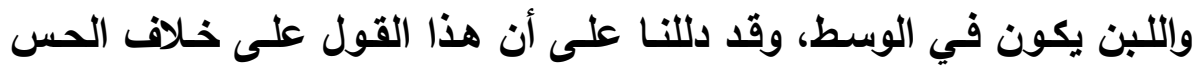

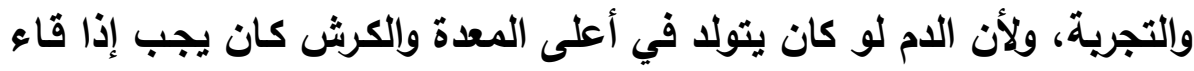

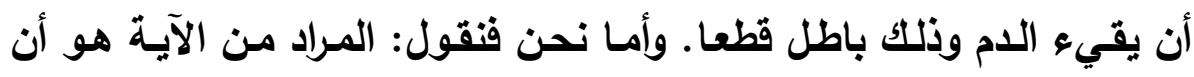

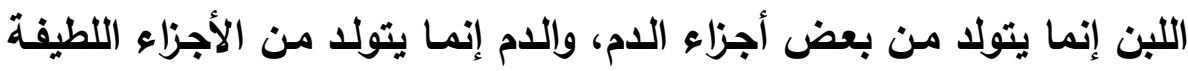
التي في الفرث "(')، وسيأتي مزيد كلام حول هذه الآية.

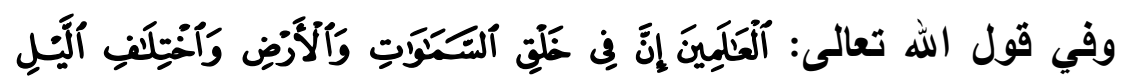

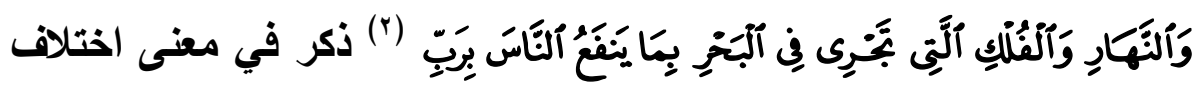

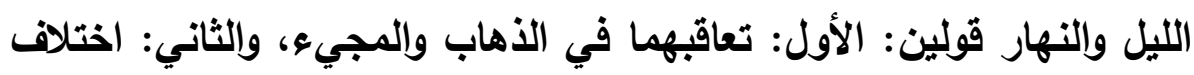
الليل والنهار في الطول والقصر والنور والظلمة والزيادة والنقصان قال فئال الكسائي: يقال لكل شيئين اختلفا هما خلفا، ثم رجح معنى ثالثاً مستدلاً له

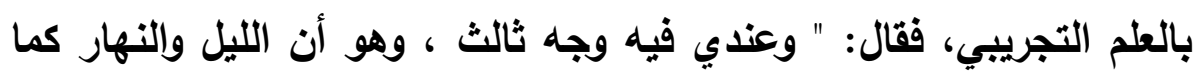

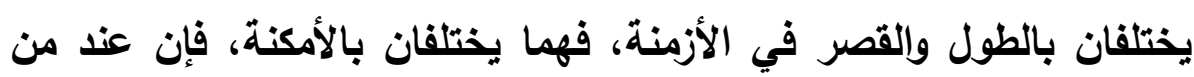

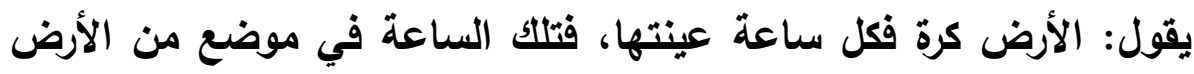

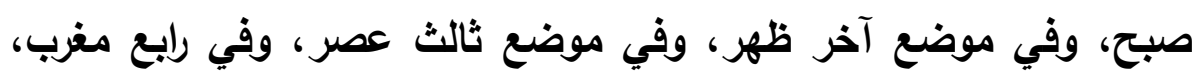

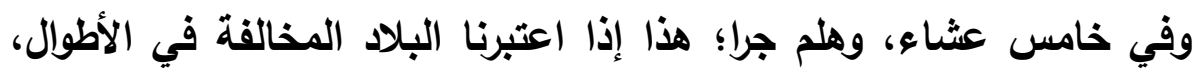

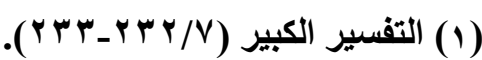

$$
\begin{aligned}
& \text { (ץ) سورة البقرة (\& (1 (1). }
\end{aligned}
$$

مجلة كلية أصول الدين بأسيوط ،العدد الرابع الثلاثون 193 م ب م 193 
أما البلاد المختلفة بالعرض، فكل بلا تكون عرضه الثمالي أكثر كانت أيامه الصيفية أطول، ولياليه الصيفية أقصر، وأيامه الشتوية بالضد من ذلك، فهذه بلهن

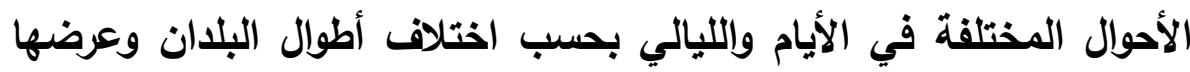
أمر مختلف عجيب "( أل. وقد قرر الرازي كروية الأرض في مواطن أخرى من تفسيره، فقال: " ثبت

بالدلائل أن الأرض كرة فكيف يمكن المكابرة فيه؟! "(†). وهذا الذي قرره الزازي فيما يتعلق باختلاف الليل والنهار بحسب الأمكنة

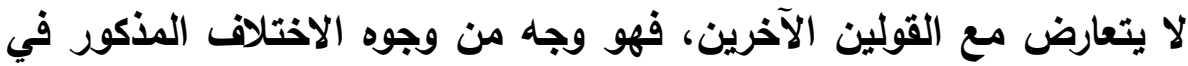
الآية أثبتته المخترعات الحديثة بجلاء.

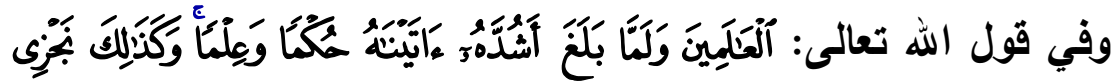

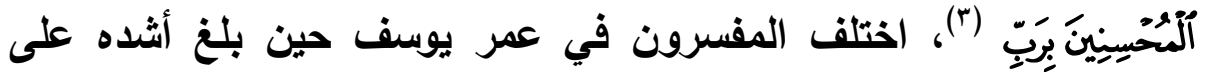
أقوال؛ منها: أن عمره حينئذٍ ثلاث وثثلاثون سنة، وقيل: ثماني عشرة سنة،

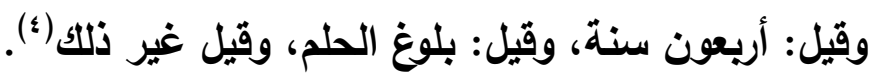

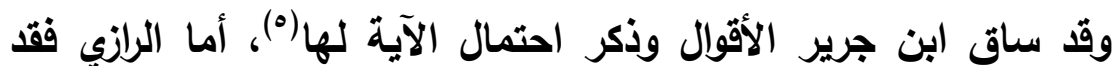

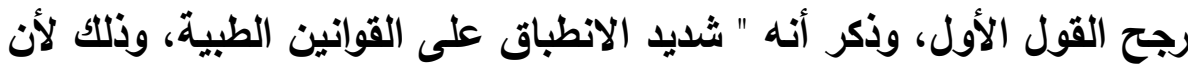
الأطباء قالوا: إن الإنسان يحدث في أول الأمر، ويتزايد كل يوم شيئاً فثيئاً

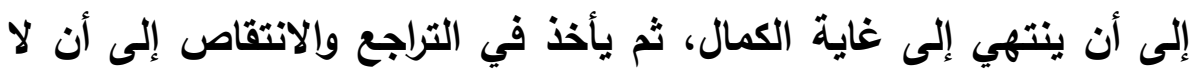

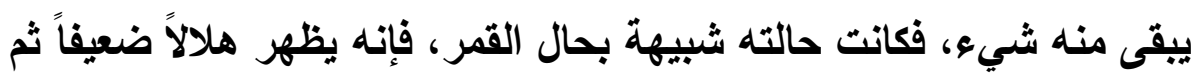

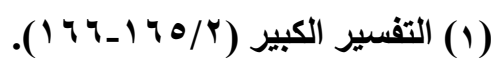

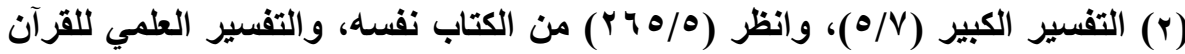

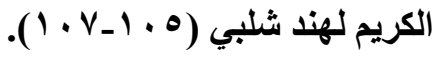

$$
\begin{aligned}
& \text { (Y) سورة يوسف (Y) (Y) (Y). }
\end{aligned}
$$

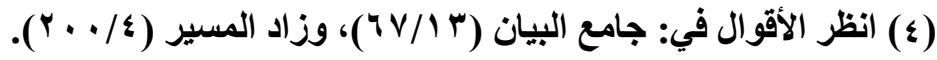

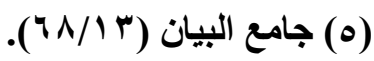

مجلة كلية أصول الدين بأسيوط ،العدد الرابع الثلاثون 194 م م م 194 
الترجيح بمكتشفات العلم التجريبي في التفسير د/عبد السلام بن صالح بن سليمان الجار الله

لا يزال يزداد إلى أن يصير بدراً تاماً، ثم يتراجع إلى أن ينتهي إلى العدم والمحاق "( (1).

ورجح قوله ابن عطية وقال: " هو أظهر الأقوال فيما نحسبه "(")، وحكى

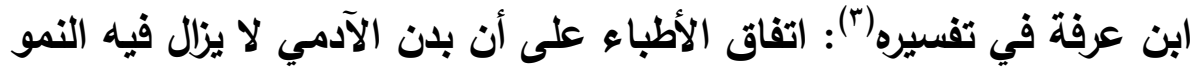
والزيادة إلى أن يبلغ ستة وثثلاثين سنة.

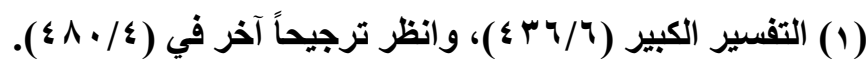

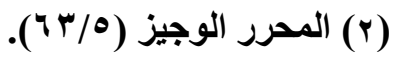

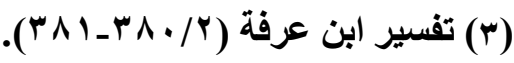

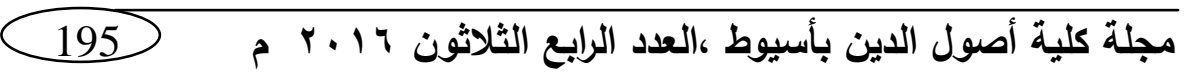




\section{المبحث الرابع}

\section{الأهور المؤثرة في الترجيح بمكتشفات العلم التبريبي}

يمكن تقسيم الأمور المؤثرة في الترجيح بمكتشفات العلم التجريبي إلى بمئ

\section{قسمين:}

\section{القسم الأول: عواهل هؤثرة في المكتشفات التجريبية.}

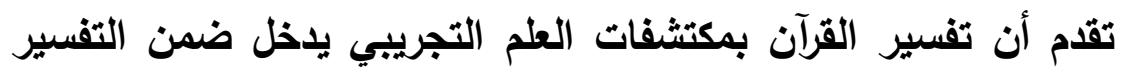

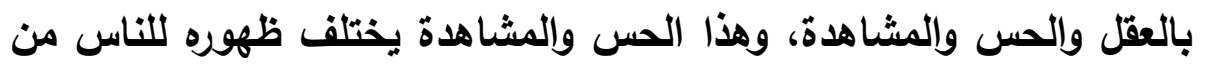

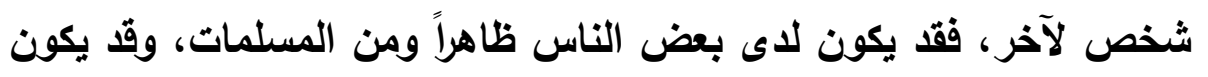

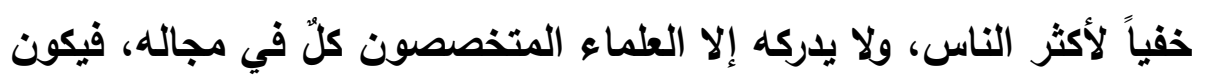
من الغيب النسبي.

$$
\text { وهذا التفاوت يرجع - والله أعلم - لأمرين: }
$$

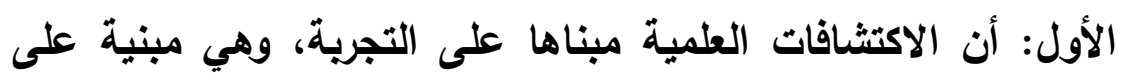

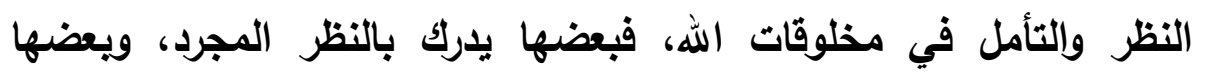

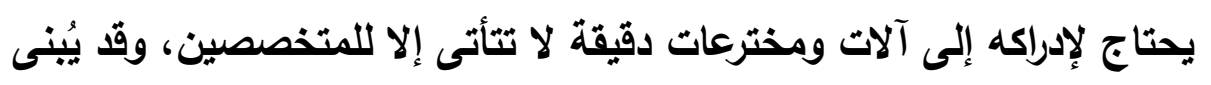

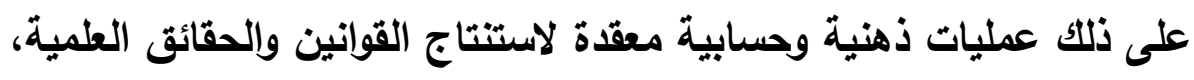

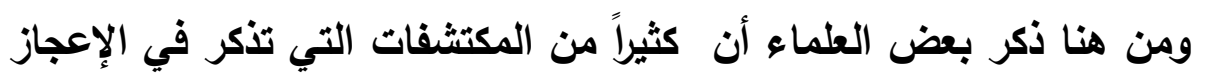

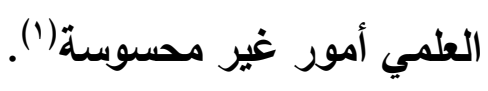
الثاني: أن نظر العلماء للاكتثافات التجريبية يقع فيه التفاوت بحسب تفاوت علومهم وأفهامهر. وقث أثشار ابن عاشور إلى قضية التفاوت في الإعجاز العلمي، فقال: "

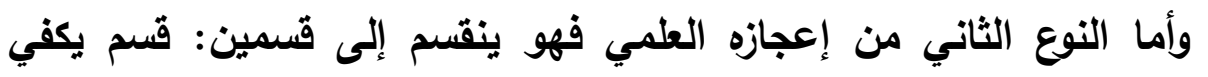

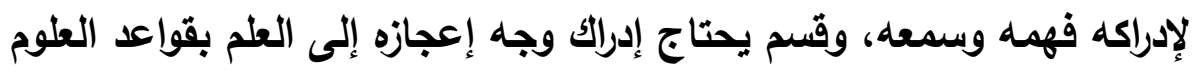

$$
\text { (1) الإعجاز العلمي إلى أين (ص V 9). }
$$

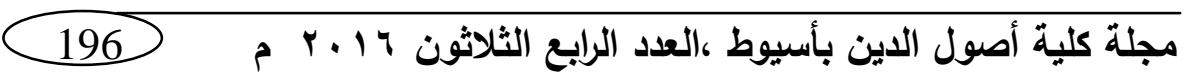


فينبلج للناس شيئاً فشيئاً انبلاج أضواء الفجر على حسب مبالغ الفهوم

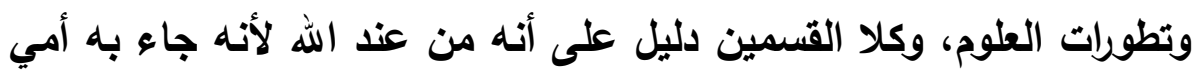

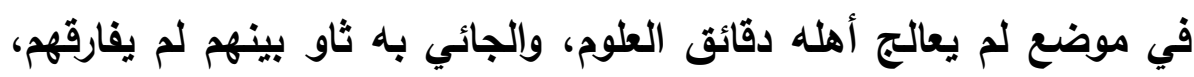

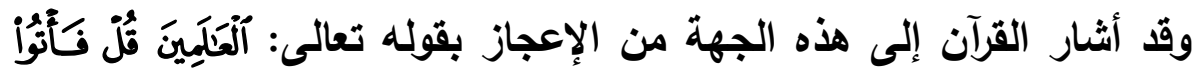

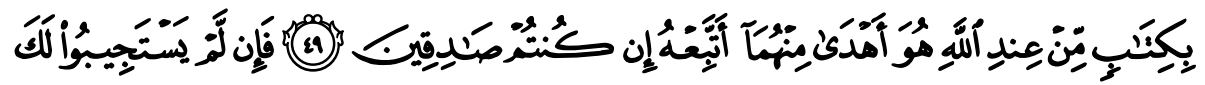

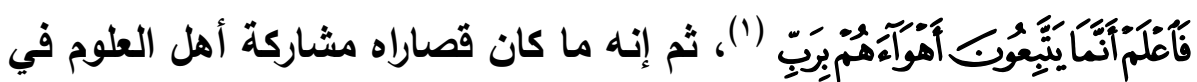

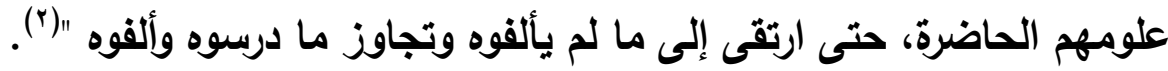
ويقول القطان: " يخطئ كثير من الناس حين يحرصون على أن يتضمن

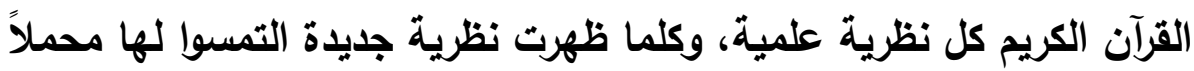
في آية يتأولونها بما يوافق هذه النظرية، ومنشأ الخطأ في هذا أنَّ العلوم تتجدد نظرياتها مع الزمن تبعًا لسنة التقدم، فلا تزال في نقص دائها دائم يكتنفه

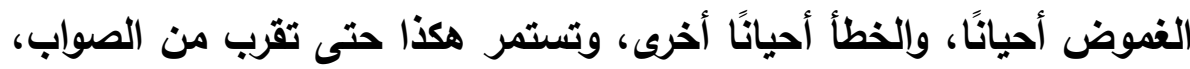

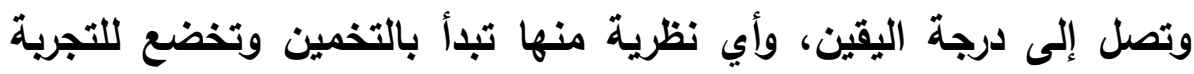

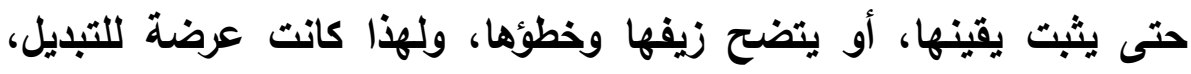

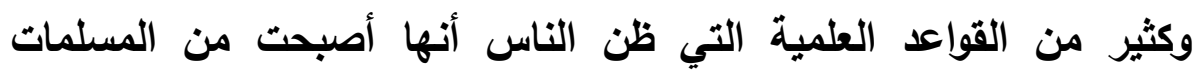
تتزعزع بعد ثبوت، وتتقوض بعد رسوخ، ثم يستأنف الباحثون تجاريهم فيها

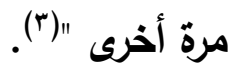
وما ذكره ابن عاثور والقطان من ظهور العلوم للناس شيئاً فشيئاً أمر ظاهر، فكم من المكتشفات أنكرها الناس أول ظهورها ونفروا منها ولم يصدقوه، وعدوها من قبيل أعمال السحرة والمشعوذين، ومن تلاعب الجن الن

$$
\begin{aligned}
& \text { (1) سورة القصص: [9 § ـ • 0]. }
\end{aligned}
$$

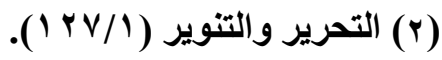

$$
\begin{aligned}
& \text { (Y) مباحث في علوم القرآن (ص Y Y Y Y Y ). }
\end{aligned}
$$

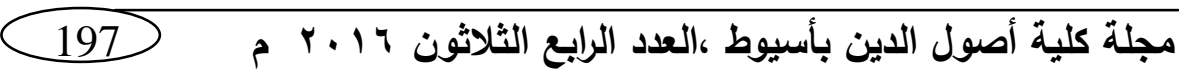


بالناس، ثم ما لبثت أن أضحت شيئاً مألوفاً بعد أن عرفوا سرها وكيف

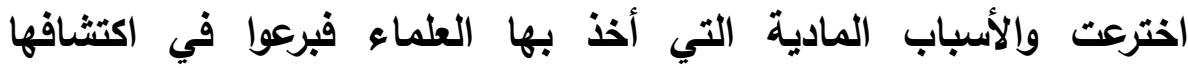
واختراعها، وهذا لون من التفاوت الذي يكون في المكتثفات التجريبية، تبدو

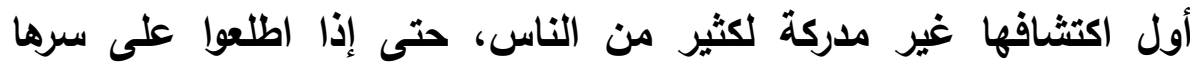
وتقتيتها ألفوها وصارت أمراً عادياً.

ومن مظاهر التفاوت في المكتثفات التجريبية أن بعض القضائات التضايا التي ذكرها القرآن الكريم مما يمكن تصنيفه ضمن العلوم التجريبية - من حيث

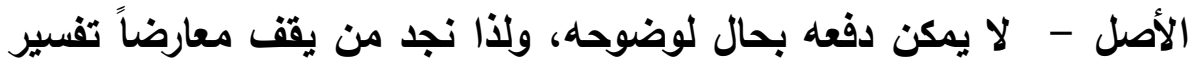
القرآن بالمكتشفات التجريبية يسلم بيعض القضال لوضوحه، ولايا التجريبية التي ذكرها القرآن، ومرد ذلك - والله أعلم كوضوحها (1). وقد تقدم النقل عن بعض المفسرين كابن القيم وإبن كثير ومن بعدهما

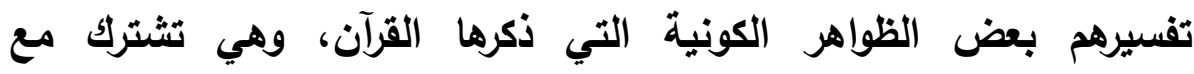

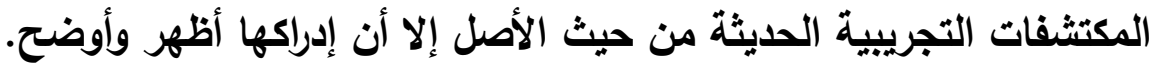

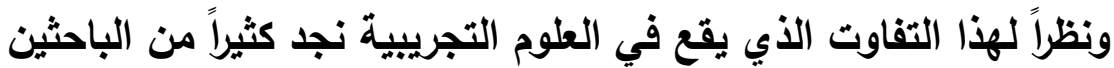
يشترطون لتفسير القرآن الكريم بالقضايا التجريبية أن تكون تلك القضايا حقائق علمية وليست نظرية، ومرد ذلك وضوح الحقائق العلمية وظهورها بخلاف النظريات التي لا تزال محل تردد وشك، وهذا الأمر يكاد يطبق عليه من تكلم في قضايا الإعجاز العلمي وتفسير القزآن به، وهم يؤكدون دومال

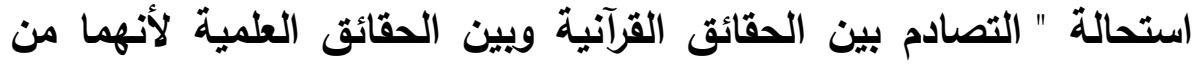

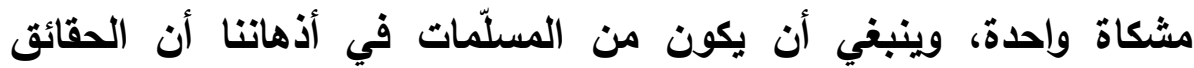

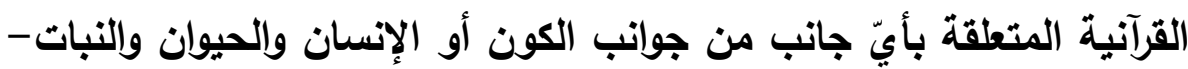

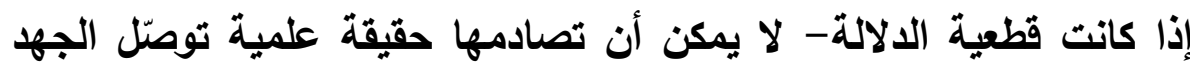

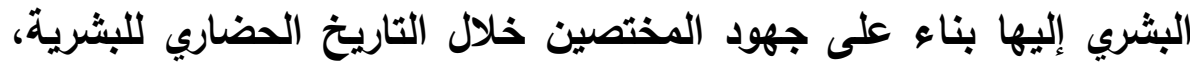


وما يثيره بعض الناس من توهم بوجود تناقض فهو سوء فهم للحقيقة

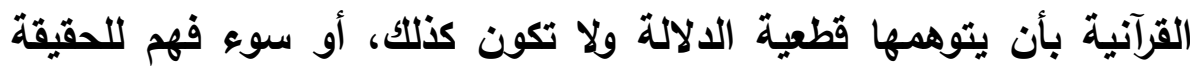

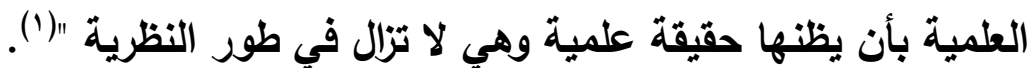

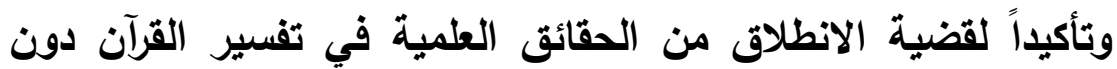

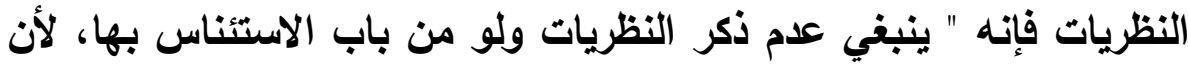

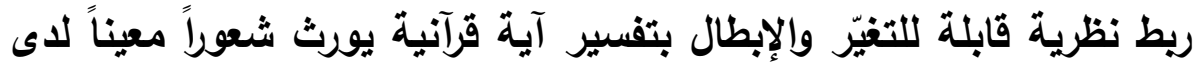

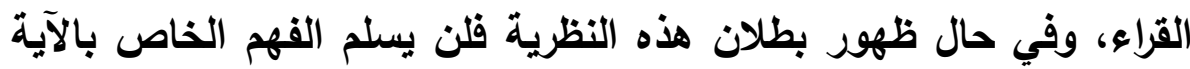

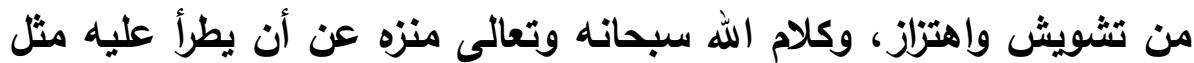

القسم الثاني: عواهل هؤثرة في دلالة الآية على المكتشف التجريبي.

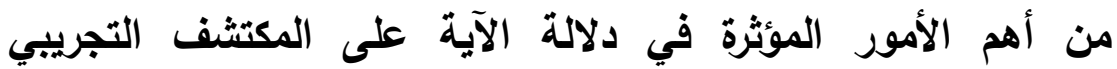
استيفاؤها لشروط التفسير الصحيح، فإن العلماء اجتهدوا في وضع القواعد

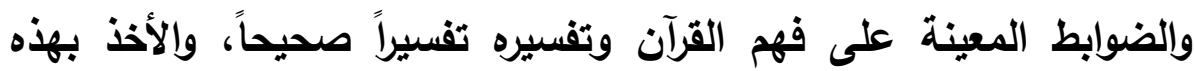
القواعد والضوابط عند النظر في اختلاف المفسرين في معاني الآيات كفيل بإذن الله - بالوصول إلى المعاني الصحيحة. وتفسير القرآن الكريم بمكتثفات العلم التجريبي غير مستثنى من هذه

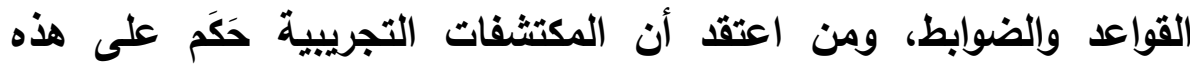
القواعد أو بعضها فهو مخطئ، مثل من قال: إن فهم القرآن الكريم في ضوء البحث العلمي ألصق بالمعنى من الفهم في ضور اللغة وحدها، وأن النهان الكلمة

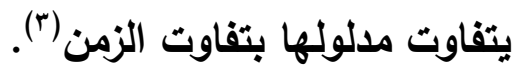

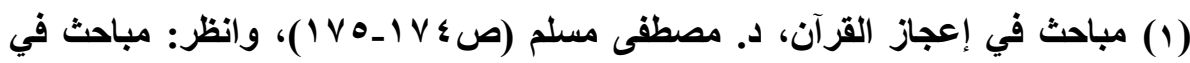

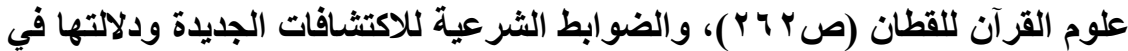

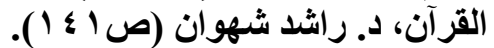

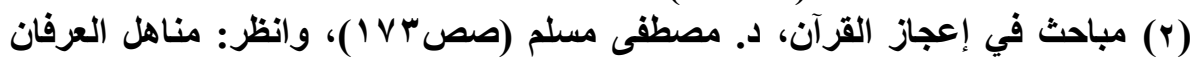

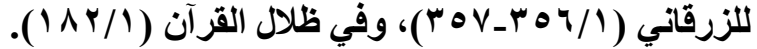

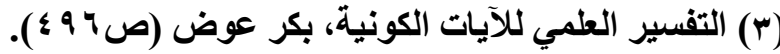

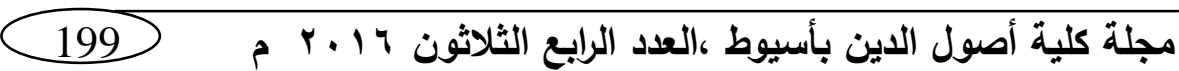


يقول الزمخثري: " وترى كثيراً ممن يتعاطى هذا العلم يجترئ إذا أعضل

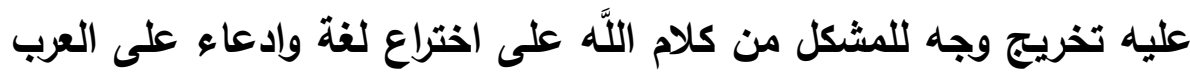
ما لا تعرفه، وهذه جرأة يستعاذ باللَّه منها "( (1).

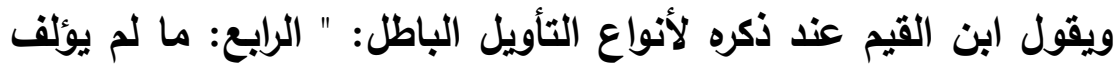
استعماله في ذلك المعنى في لغة المخاطب، وإن ألف في الاصطلاح الحادث،

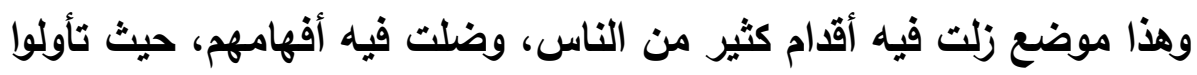

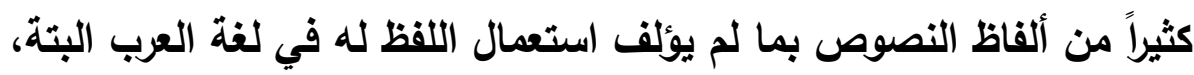

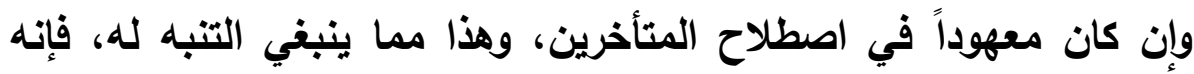
حصل بسبيه من الكذب على الله ورسوله ما حصل "((ץ).

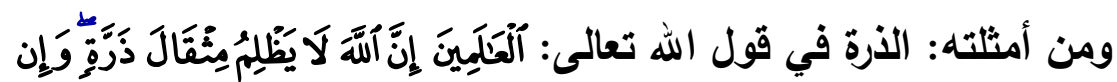

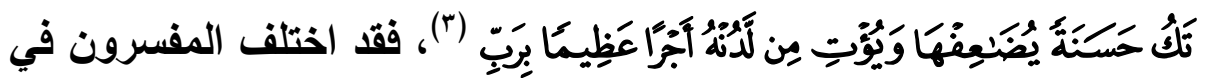
معناها على أقوال؛ منها: النملة الصغيرة، أو ذرة التراب، أو الهباءة، أو الخردلة:(๕).

لكنها تعني في اصطلاح الكيميائيين أصغر جزء من العنصر الكيميائي

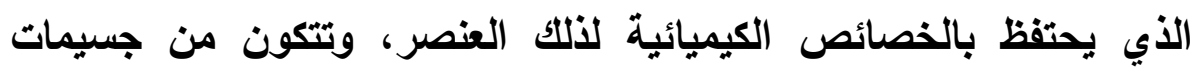

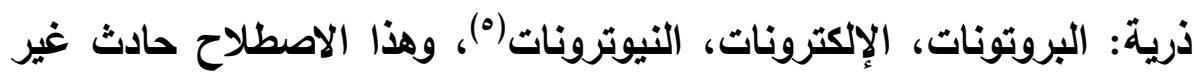

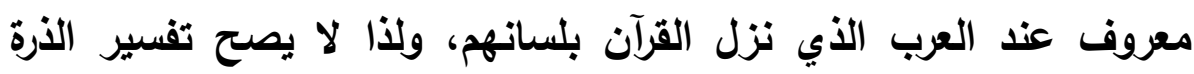

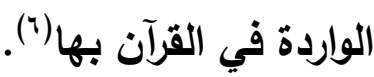

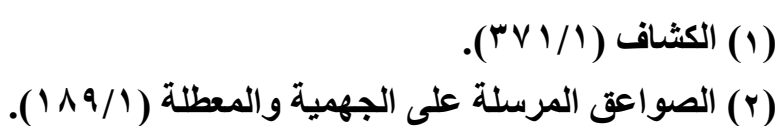

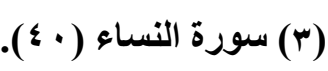

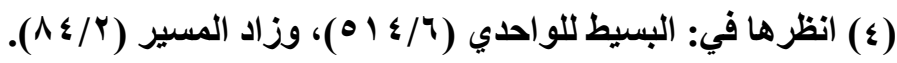

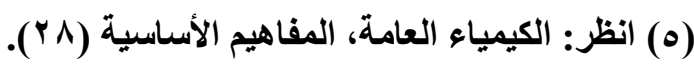
(؟) انظر الإعجاز العلمي إلى أين (ص +9).

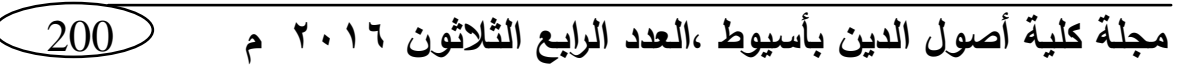


ومما يتعلق بهذه القضية أن دلالة الآيات على المكتثفات التجريبية إن صحت لا تعدو - في الغالب - إثارات لطيفة عابرة، وعليه فليس من الابله الصواب الزج بتلك الإثارات وتحميلها فوق ما تحتمله ووضعها موضع السباق مع البحوث العلمية) (1)

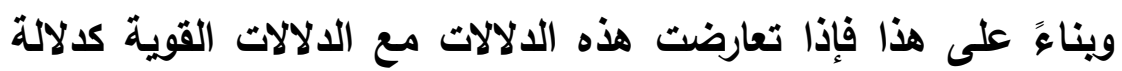
النص ودلالة الظاهر ونحوهما فإنها تقلم عليها. ومن الأمور المهمة عند النظر في الترجيح بالمكتثفات التجريبية أن أن النهان

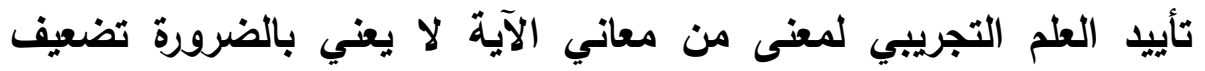
المعاني الأخرى وإسقاطها، ومن أمثلته:

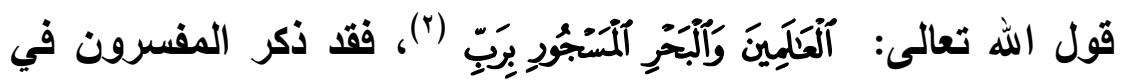
معنى المسجور عدة أقوال، منها: الأول: المملوء، وجاء عن قتادة، ورجحه ابن جرير وابن عاشور الثاني: الموقد، وجاء عن علي ومجاهد وابن زيل. الثالث: الممنوع، وجاء عن ابن عباس والسدي، والمعنى أنه مكفوف وفئ عن الأرض لئلا يغمرها فيغرق أهلها.

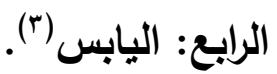
وقد رجح ابن جرير القول الأول، وقال: " وأولى الأقوال في ذلك عندي

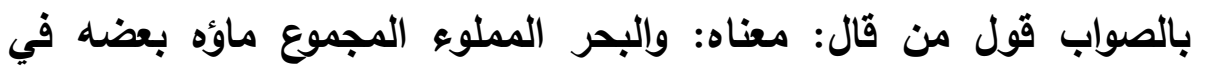

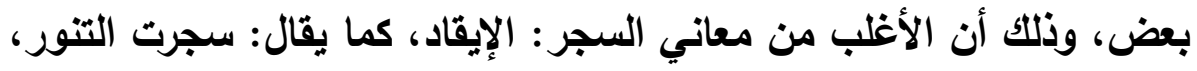

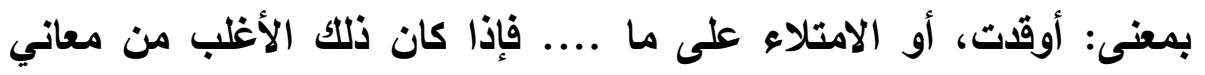

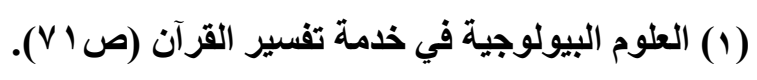

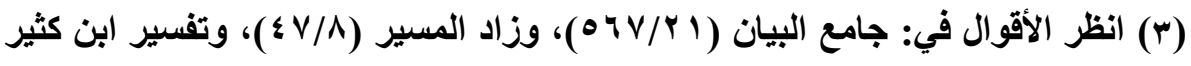

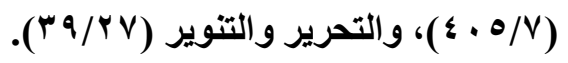

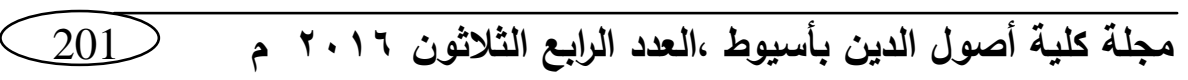


السجر، وكان البحر غير موقد اليوم، وكان الله تعالى ذكره قد وصفه بأنه

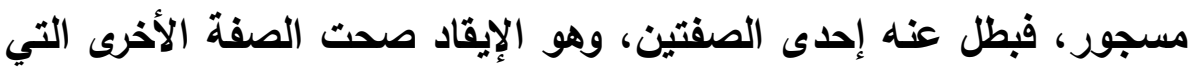
هي له اليوم، وهو الامتلاء، لأنه كل وقت ممتلئ "( ").

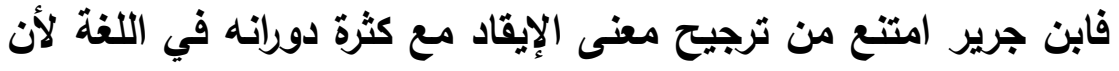
البحر في نظره غير موقد، ومفاده أنه لو ثبت له لقال بها.

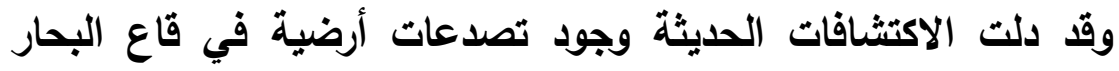
والمحيطات يتافق من خلالها حم منصهرة على امتداد مئات الأمتار، والمنظر يوحي بأن البحر يحترق حتى إن الذي يراقب هذه البراكين وحممها

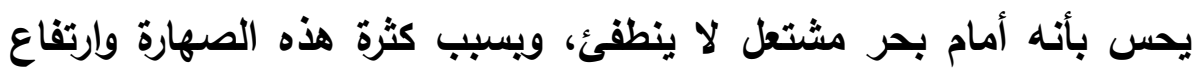

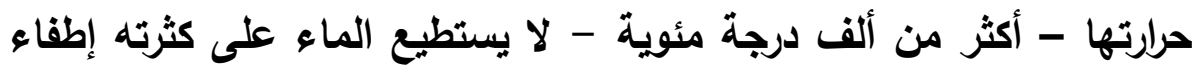

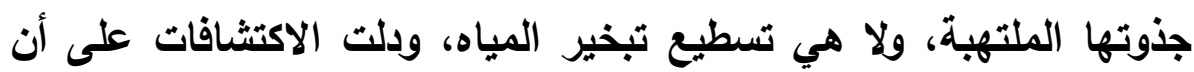
البراكين في قاع المحيطات أكثر عدداً وأعنف نشاطاً من البراكين على سطح

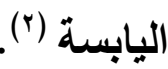

ومع دلالة الاكتثافات الحديثة على إمكانية أن تكون قيعان البحار

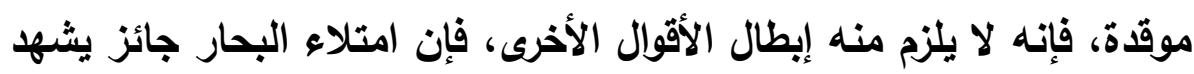

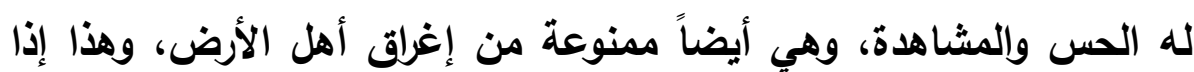
كان المراد بالبحار في الآية البحار الموجودة في الدانيا.

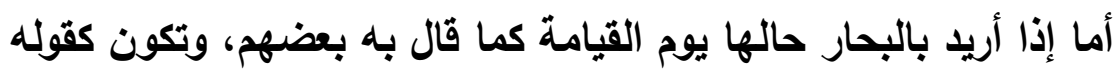

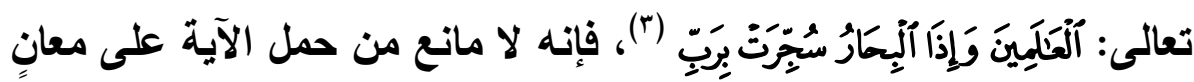

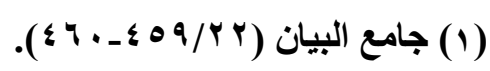

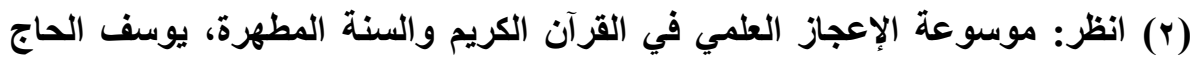

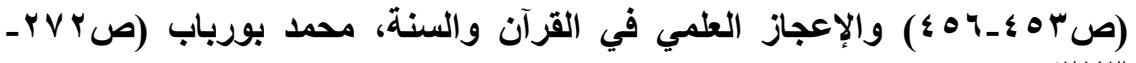

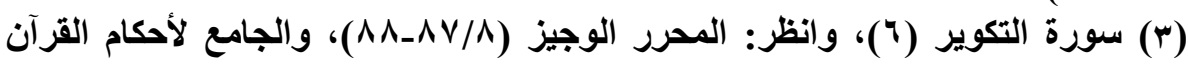

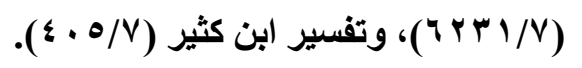

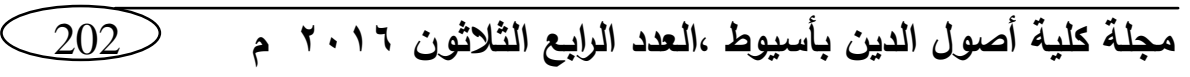


أكثر، ويمكن الجمع بينها على أن هذه من المراحل التي تمر بها البحار في ذلك الزمان، فعبر بلفظ يل على هذه المراحل جميعها بأن تتفجر البحار ويفيض بعضها على بعض، حتى تصير بحراً واحداً ممتلئاً، ثم توقث بالنار

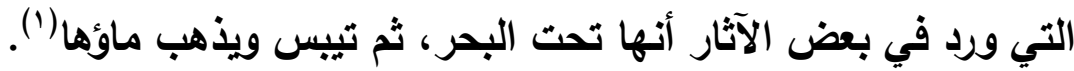
وكون الاكتثافات الحديثة أثثتت إمكانية أن البحار تتقا قيعانها، وهو

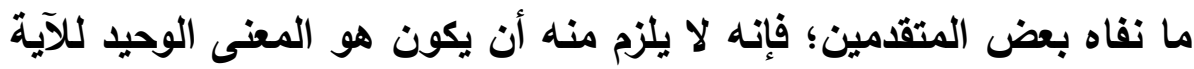
وأن ما عداه غير صحيح. إن مما ينبغي أن يدركه من يريد تفسير القرآن الكريم في ضوء

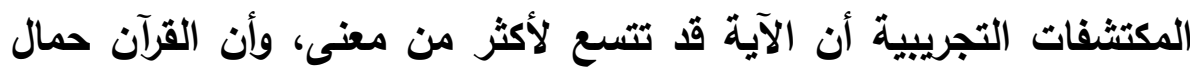

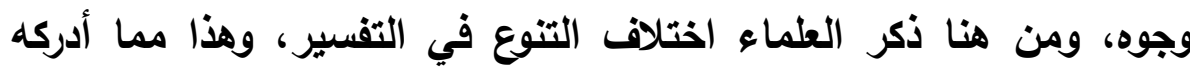
السلف وفسروا القرآن الكريم في ضوئه، وكثير من خلافهم يرجع إليه،

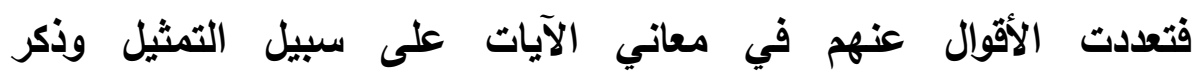
الأنواع.....، وقد جاء عن سفيان بن عيينة قوله عن تفاسير سلفه: ليس

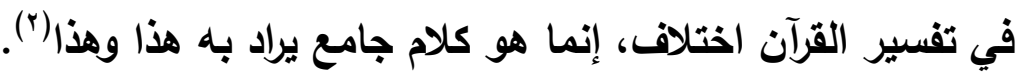

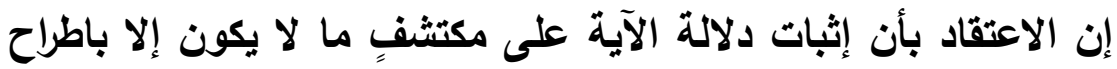

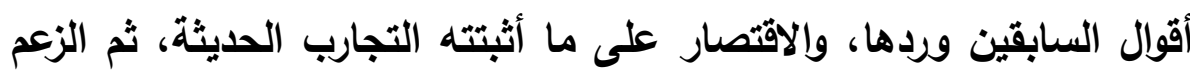
بأن سلف الأمة كانوا مخطئين في فهم القرآن الكريم، أو أن نظرتهم لتفسيره

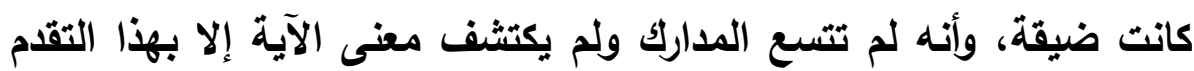

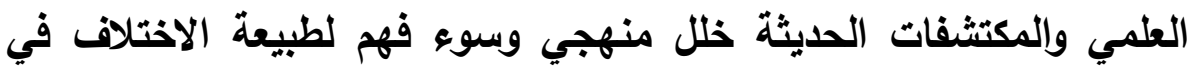
فهم القرآن وتفسيره(r).

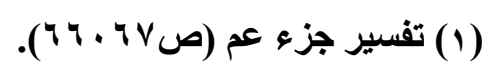

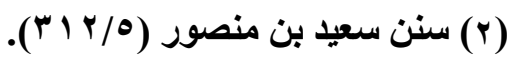

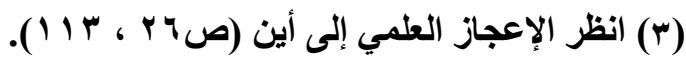

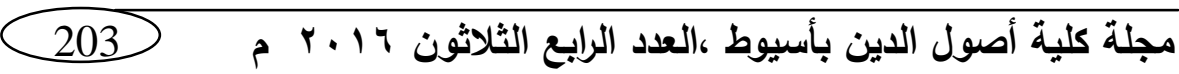




\section{المبحث الخاهس \\ هن صور الترجيح بمكتشفات العلم التجريبي

$$
\text { وفيه مطلبان: }
$$

المطاب الأول: صور هقبولة الترجيح بمكتشفات العلم التجريبي:

الصورة الأولى: تقوية أحد الأقوال في معنى الآية، ومن أمثلته أن

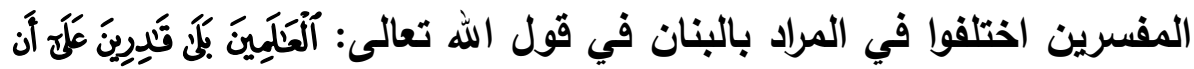

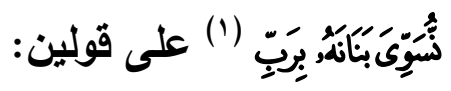

الأول: جعل أصابع يديه ورجليه شيئاً واحداً كخف البعير، أو حافر اللابة، فلا يأخذ ما يأكل إلا بفيه كسائر البهائم، وهذا القول مروي عن ابن الائ عباس وعكرمة والحسن وقتادة وغيرهم، ونسبه البغوي وغيره للجمهور (؟).

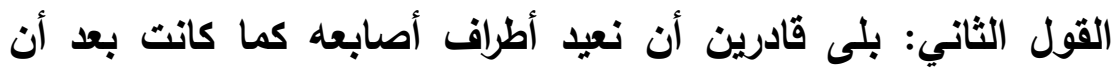
تبلى، وهذا القول أظهر وأقوى بدلالة السياق كما أشار إليه ابن قتيبة وغيره: قال ابن قتيبة: " هذا رد من الله عليهم، وذلك أنهم ظنوا أن الله لا ينشر

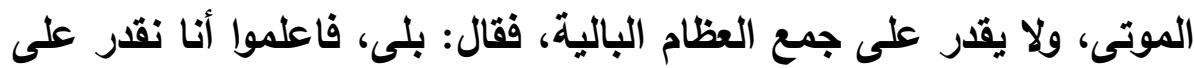

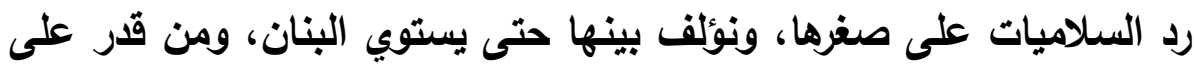
هذا فهو على جمع كبار العظام أقرر "("). وقال الزجاج: " والذي هو أثشكل بجمع العظام بلى نجمعها قادرين، على الى

تسوية بنانه على ما كانت، وإن قل عظامها وصغرت ويلغ منها البلى "( (؛).

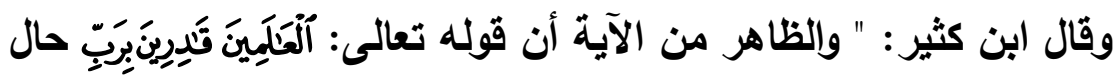

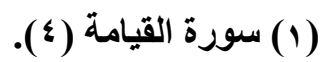

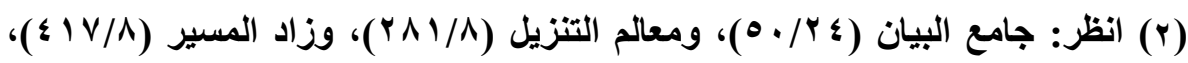

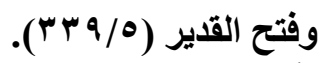

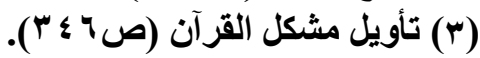

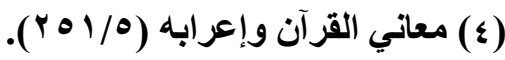

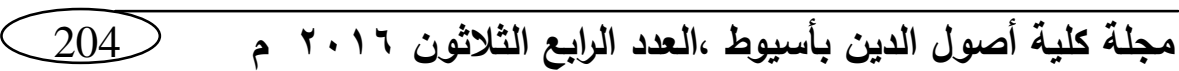




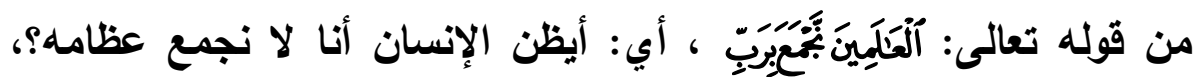

بلى سنجمعها قادرين على أن نسوي بنانه "( '). ومما يقوي هذا القول إضافةً إلى دلالة السياق ما كثفه العانه العلم الحديث

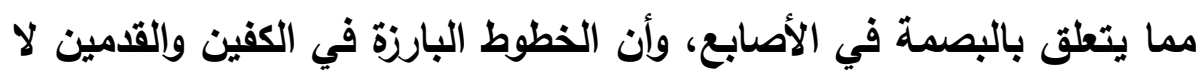

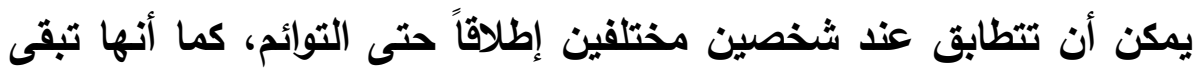

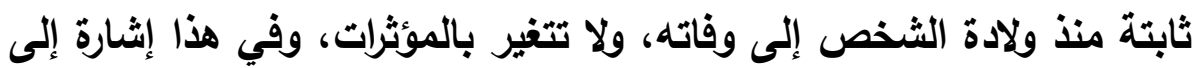

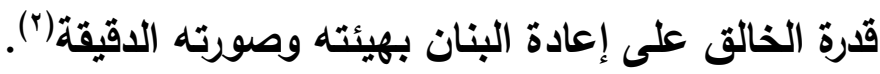
الصورة الثانية: أن تسهم الاكتثافات الحديثة في زيادة معنى الآية

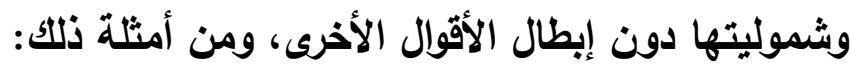

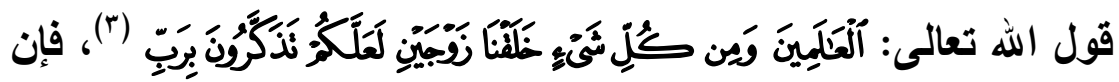
للمفسرين في المراد بالزوجين قولان: الأول: أن المراد بهما صنفان ونوعان، فعن مجاهد قال: الكفر والإنيمان والثقاوة والسعادة، والهاى والضلالة، والليل والنهار، والسماء والأرض،

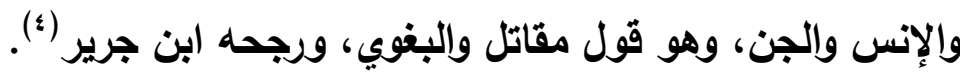

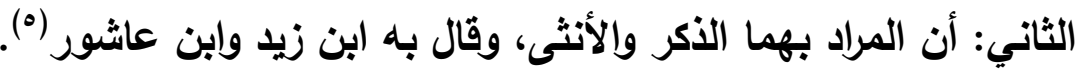

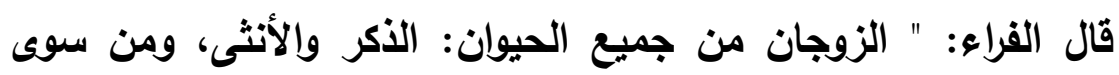

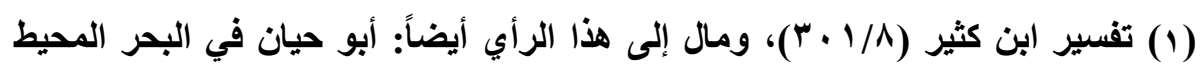

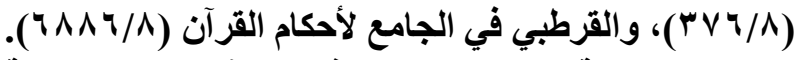

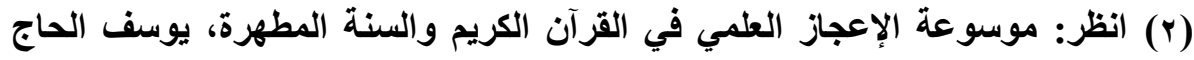

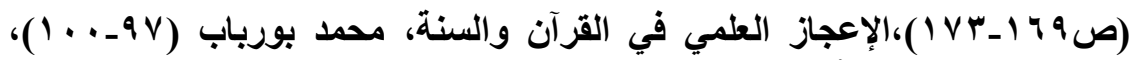

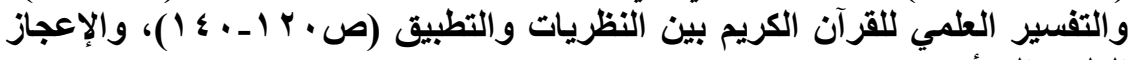

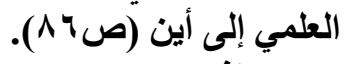

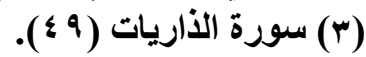

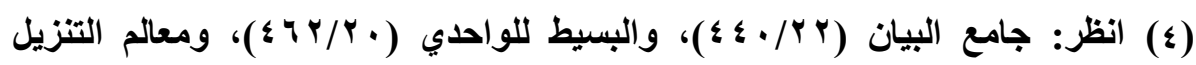
( 1 (

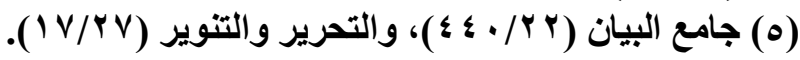

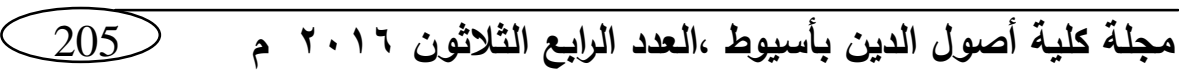


ذلك: اختلاف ألوان النبات، وطعوم الثمار، ويعض حلو، ويعض حامض،

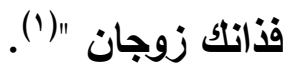

وقال الواحدي: " أي: صنفين ونوعين، فالزوجان في الحيوان الذكر

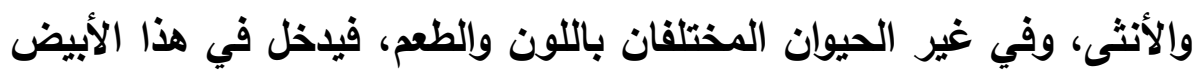

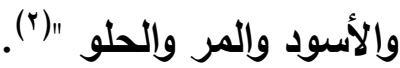
ويلحظ في كلام الفراء والواحدي قصر الزوجين في الحيوان على الذكر والأنثى، وفي غير الحيوان على الصنف والنوع، وعلى تفسير الزوجين بالذكر فئر الأني

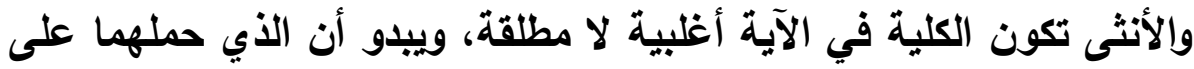
هذا التوجيه أن الأي يدركونه في وقتهم أن الازدواج ظاهر في الإنسان

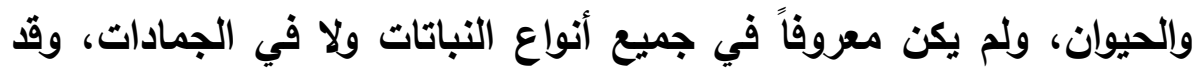

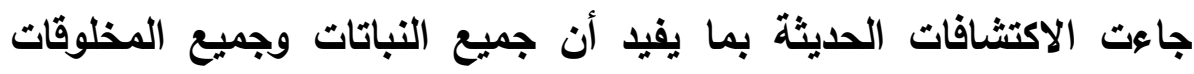
قائمة على الزوجية) (َ). وفي ظلال القرآن (؛): " وهذه حقيقة عجيبة تكثف عن قاعدة الخلق في

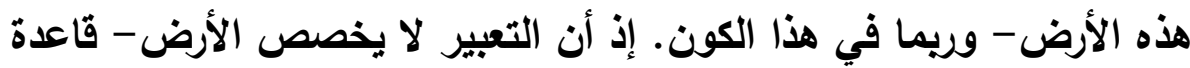

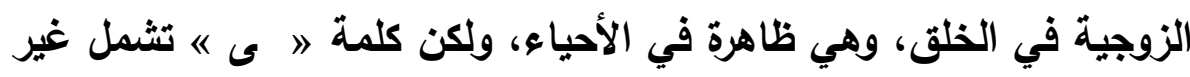
الأحياء أيضاً، والتعبير يقرر أن الأثشياء كالأحياء مخلوقة ولى فلى أساس

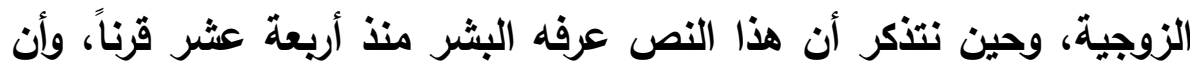

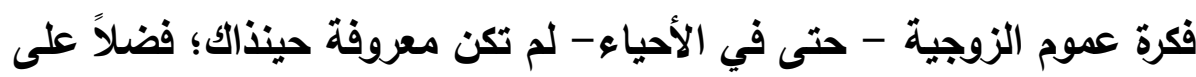

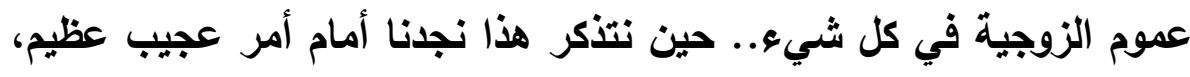
وهو يطلعنا على الحقائق الكونية في هذه الصورة العجيبة المبكرة كل التبكير،

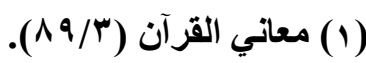

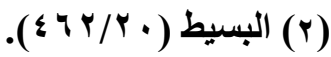

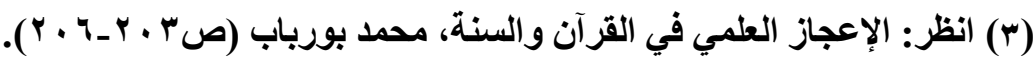

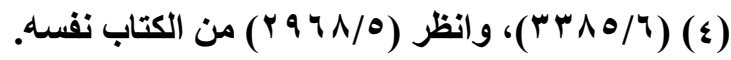

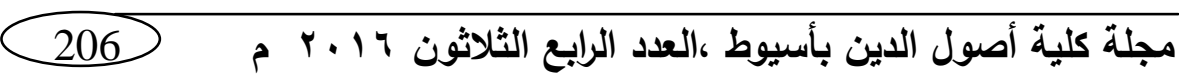


كما أن هذا النص يجعلنا نرجح أن البحوث العلمية الحديثة سائرة في طريق الوصول إلى الحقيقة، وهي تكاد تقرر أن بناء الكون كله يرجع إلى الذئ الذرة. وأن الذرة مؤلفة من زوج من الكهرياء: موجب وسالب ".

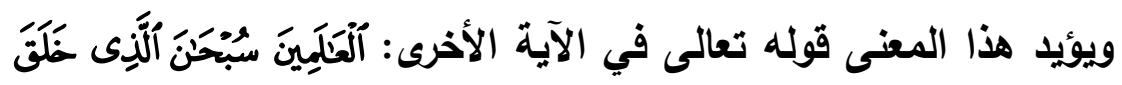

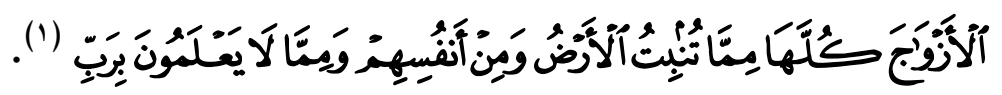

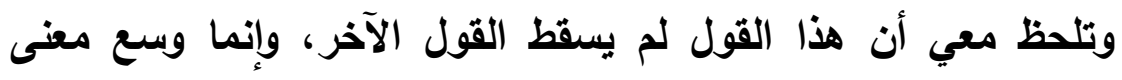
الآية، وأضاف أن الزوجية أعم من أن تكون في الحيوان ويعض النباتات، لتول

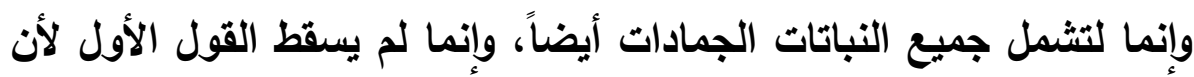
مجيء الزوج بمعنى الصنف والنوع مستعمل في القزآن الكريم، كقوله تعالى:

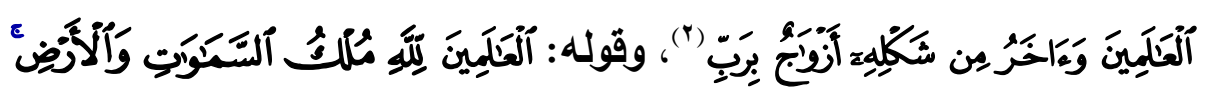

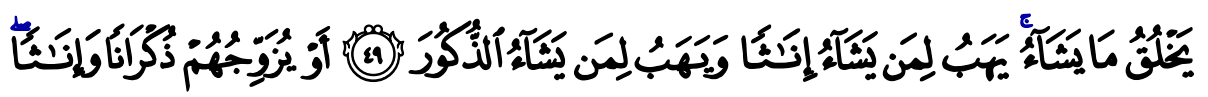

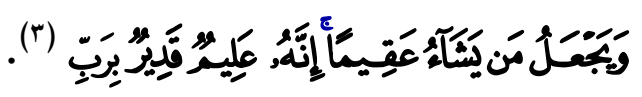
الصورة الثالثة: تضعيف أحد الأقوال في معنى الآية، ويترتب عليه تقوية التية

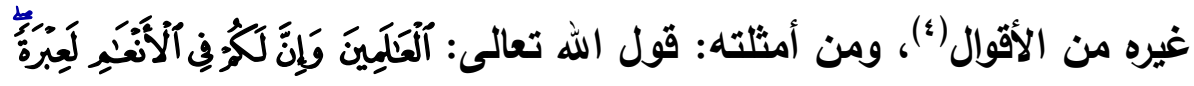

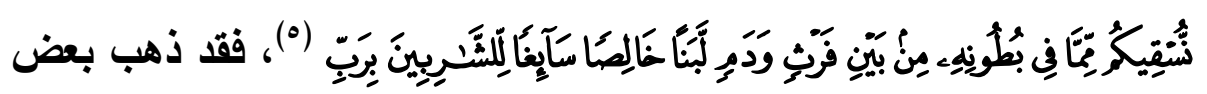

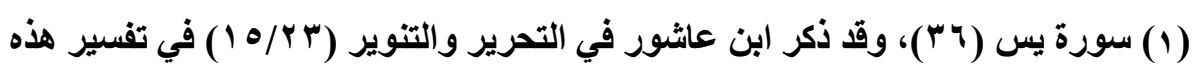

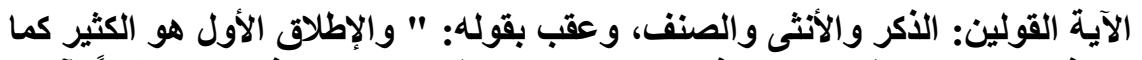

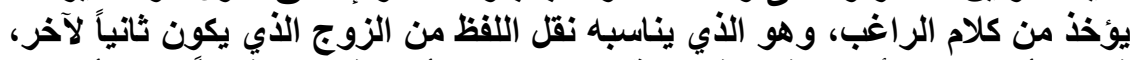

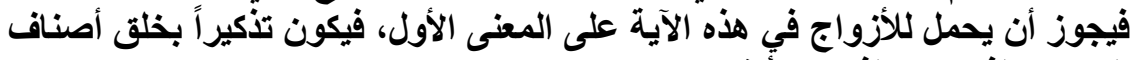

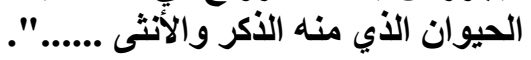

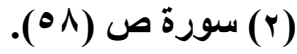

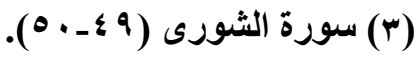

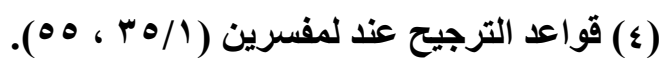

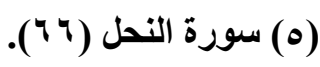

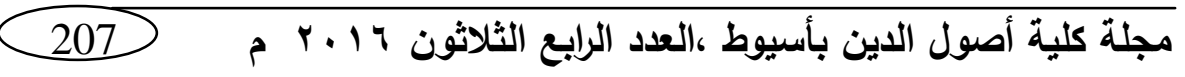




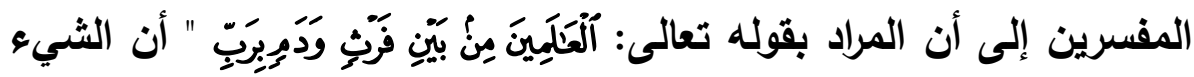
الأي تأكله يكون منه ما في الكرش، وهو الفرث ويكون منه الام، فيكون

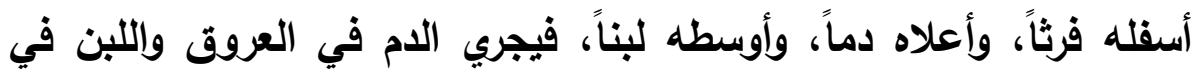
الضروع، ويبقى الفرث كما هو "('). وقد سبق كلام الرازي حوله وتضعيفه له، وأن الام واللبن لا يتولدان البتة في الكرش، واستدل عليه بالحس بأن هذه الحيوانات تذبح ذبحاً متوالياً،

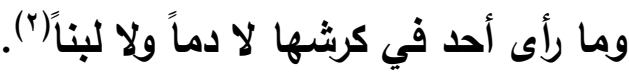
وما ذكره الرازي أيدته الدراسات الحديثة، فبعد هضم الطانيات الطعام وتحويل

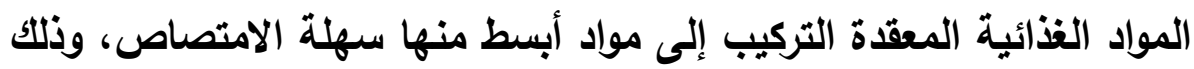

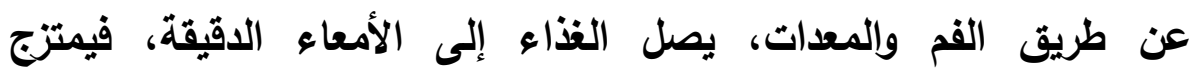

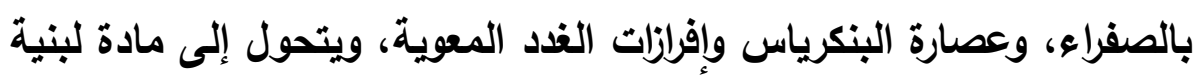

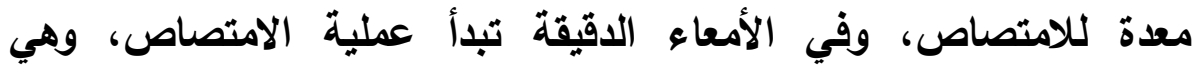

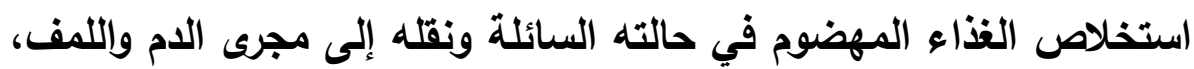
فتمتص الأمعاء الدقيقة بواسطة الخلايا الطلائية الاسطوانية معظم الغذاء

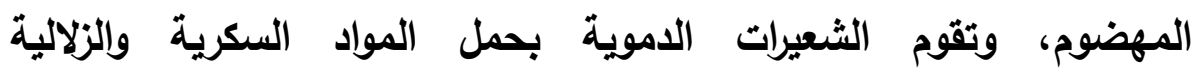
المهضومة، وتقوم اللمفاوية بحمل المواد الدهنية المهضومة، وفي الأمعاء الغليظة يتم امتصاص بواقي الذذاء والماء، فيصل ما تحمله الثعيرات الدموية إلى الكبل، فيختزن السكر، ثم يذهب إلى القلب، وتحمل الأوعية

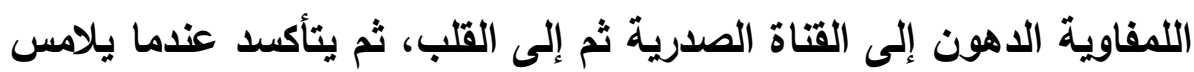
الهواء الرئتين، ثم يتوزع في الأنسجة عن طريق الشرايين الممتدة خلال

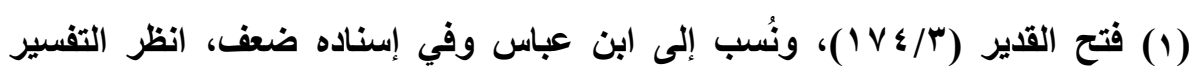

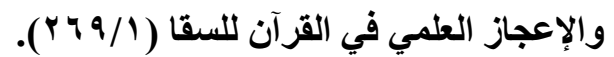

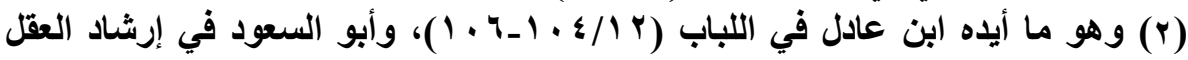

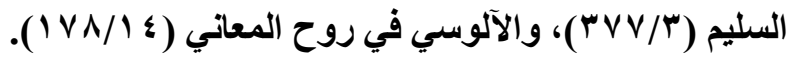

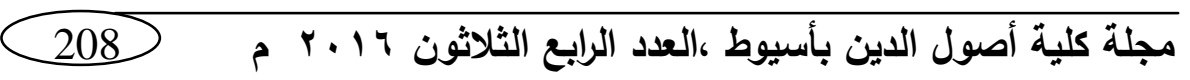


الجسم، ومن هذه الثرايين شريان كبير يسمى بالأورطة يمتد فرع منه إلى أسفل داخل الضرع، ويحيط بالضرع شرايين كبيرة من الشعيرات التي تمد أسناخ الغدة اللبنية بالدم، وتنظم إلى الأسناخ ضفائر كبيرة من الأوردة فئرة

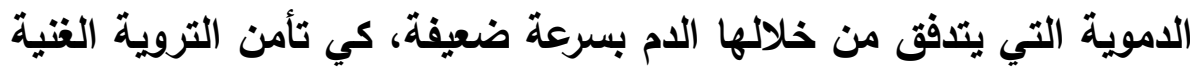
للضرع، وتتهيأ الظروف المناسبة لتكوين الحليب('). ويناء على هذا فالبينية في الآية لا يراد بها ما ذهب إليه أصحاب القوبن القول

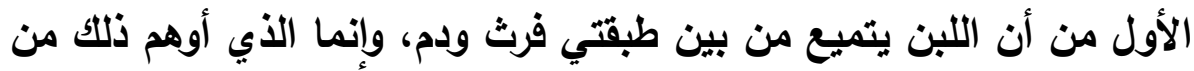

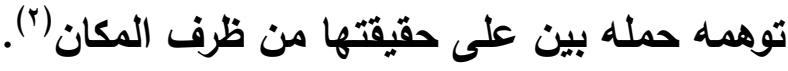

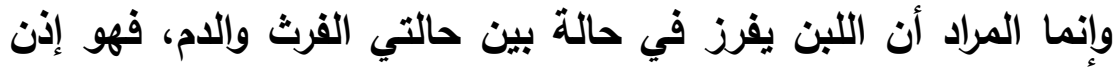

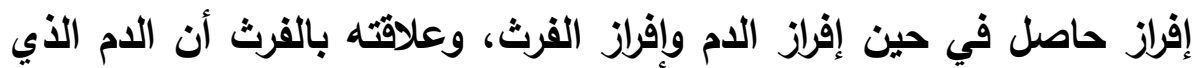
ينحر في عروق الضرع يمر بجوار الفضلات البولية والثقلية، فتفرزه غدد الضرع لبنا كما تفرزه غدد الكليتين بولا بدون معالجة زائدة(").

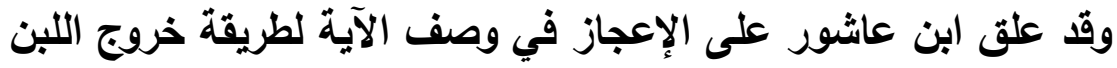
من بين الفرث والام فقال: " وهذا الوصف العجيب من معجزات القرآن العلمية، إذ هو وصف لم يكن لأحد من العرب يومئذ أن يعرف دقائق تكوينه،

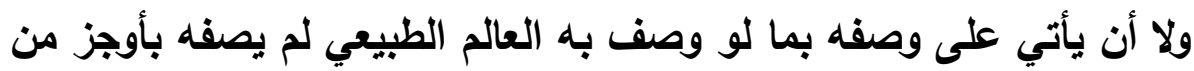

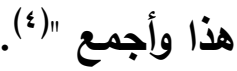

\section{المطلب الثاني: صور غير هقبولة للترجيح بمكتشفات العلم التجريبي:}

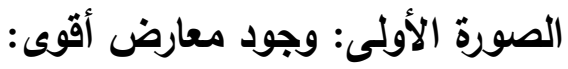
قـ تفسر الآية بما يترتب عليه معارضة التفسير لما هو أقوى، ومن الموضن

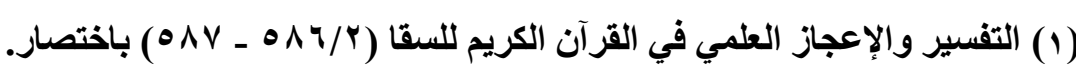

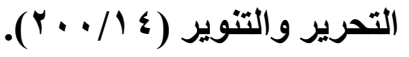

$$
\begin{aligned}
& \text { (r) المصدر السابق. }
\end{aligned}
$$

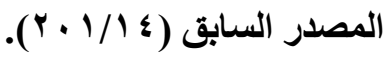

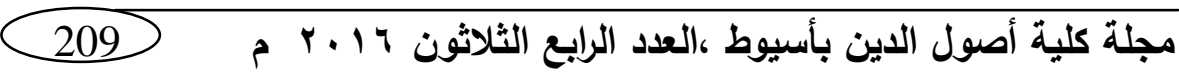


أمثلته الأمر بالسير في الأرض، وقد ورد في القرآن في مواضع؛ منها قول

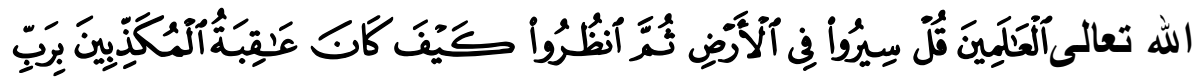

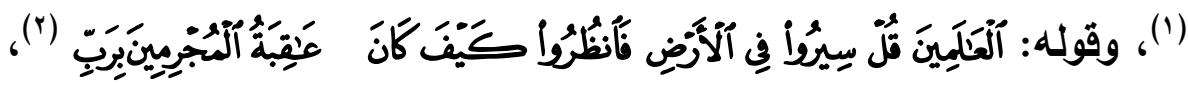

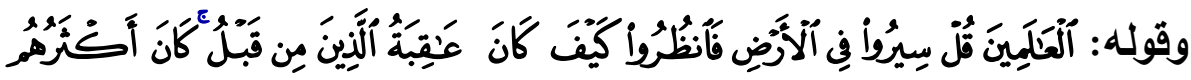

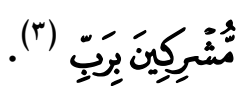

والمراد بالسير في الأرض يحتمل السير بالعقول والفكر، ويحتمل السير

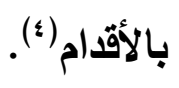

قال أبو حيان: " والظاهر أن السير المأمور به، هو الانتقال من مكان

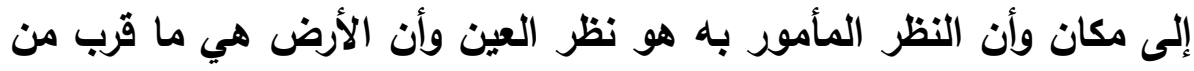

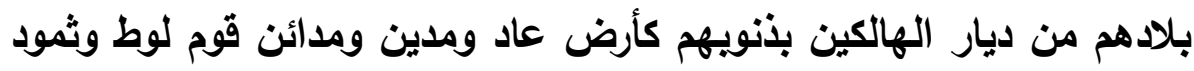

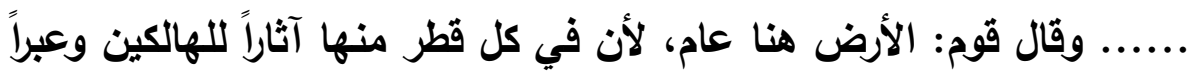

$$
\text { "للناظرين" ((). }
$$

وعبارات المفسرين تحوم حول هذا المغنى، وأن الأرض هي التي نسير

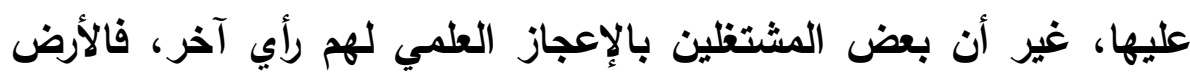

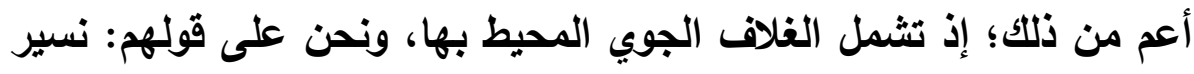

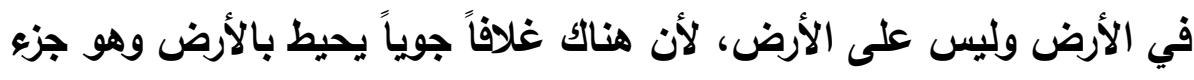

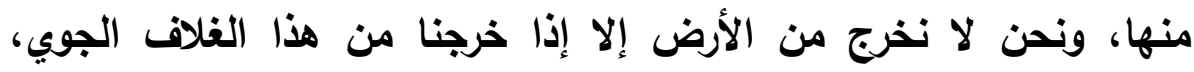

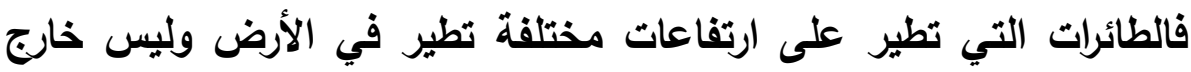

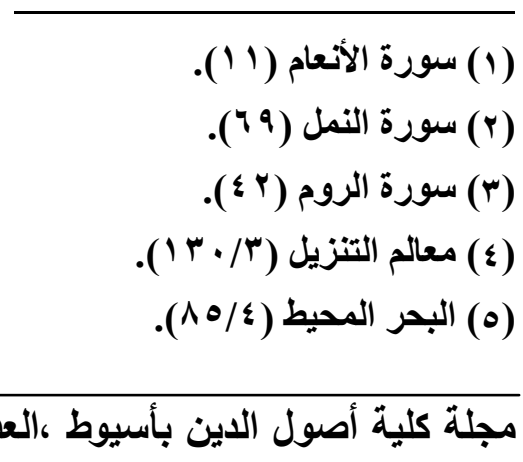

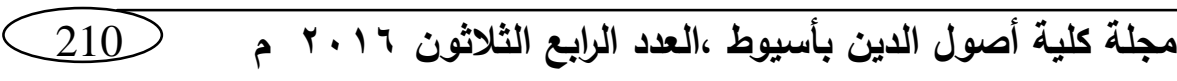


الأرض، ولكن الأي يخرج من الأرض: هي سفن الفضاء التي تجاوز الغلاف

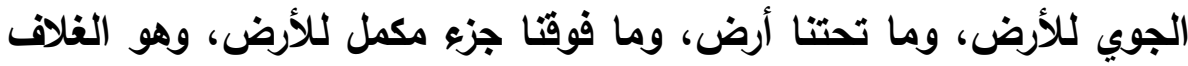

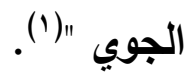
وهذا التفسير فيه عدة مخالفات لما يجب أن يلتزم من أراد الترجيح

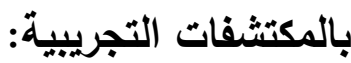
أولاً: أن هذا التفسير للأرض مبني على اصطلاح حادث لأهل العلم

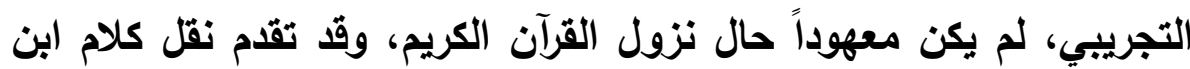
القيم حول ذلك. ثانياً: أن حرف " في " الوارد في الآية يأتي بمعنى على، وهو المراد في الآية، والمعنى: سيروا على الأرض، وهذه الآية كقوله تعالى: ألَكَلمِينَ

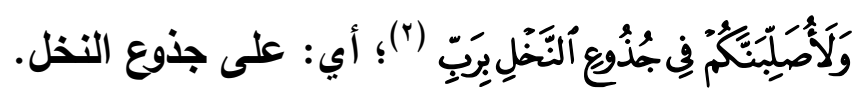

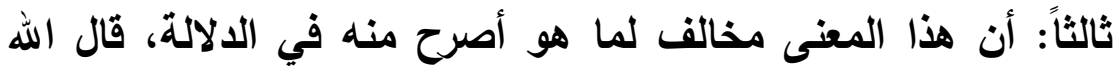

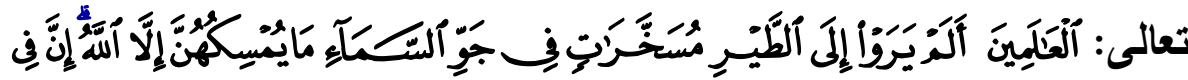

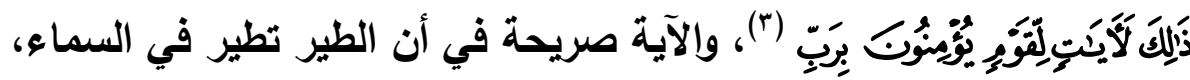

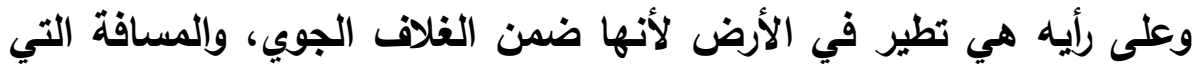

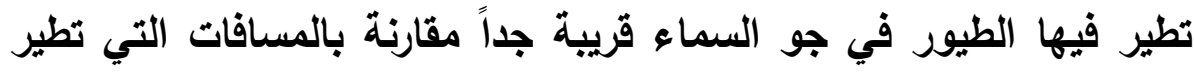

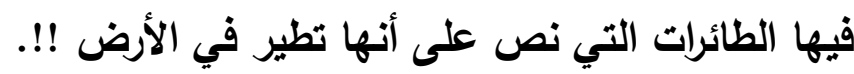

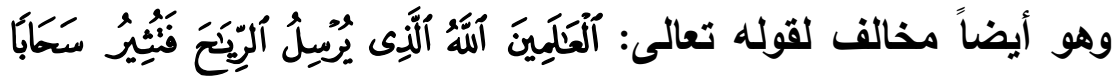

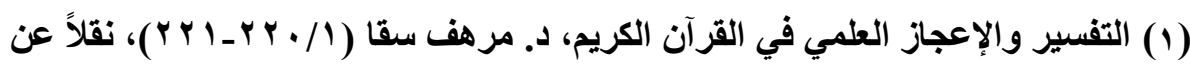

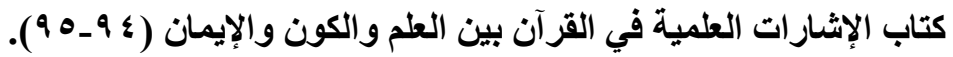

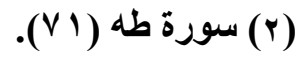

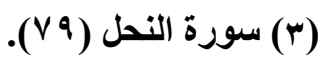

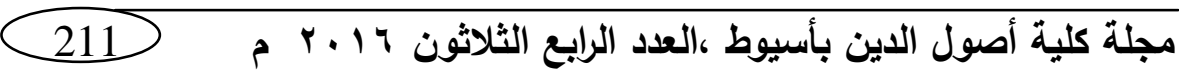




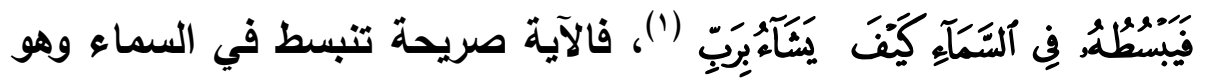
ضمن الغلاف الجوي وليس خارجه، والمراد بالسماء في هذه الآية والآية

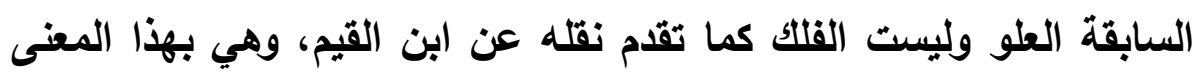

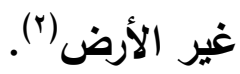
الصورة الثانية: أن يترتب على تفسير الآية بالمكتثفات التجريبية أمور باطلة.

ومن أمثلته تأويل معجزات الأنبياء بما دلت عليه المكتثفات التجريبية مما يجعلها أموراً عادية غير خارقة للعادة، وهذا يلزم منه إبطال المعجزات(").

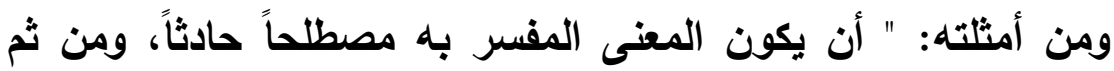
فإنه لا يمت للفة العرب بصلة، وتفسير النصوص بالاصطلاح الحادث من

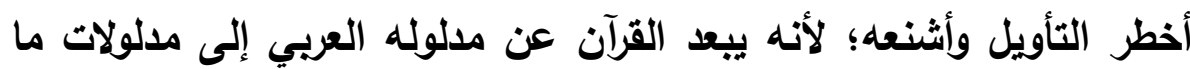
أنزل الله بها من سلطان "(\{)، وقـ تقام المثال عليه قريباً.

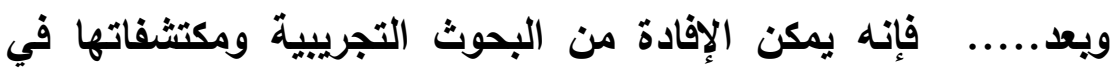
تقريب معاني الآيات، وتوظيفها عند النظر في أقوال المفسرين والمقارنة بينها، واستخدامها قرينة ترجيحية بعد الالتزام بضوابط المكتشفات التجريبية وتفسير القرآن بها والتي مر بعضها، وللمجتها أن يستذدها مع القرائن

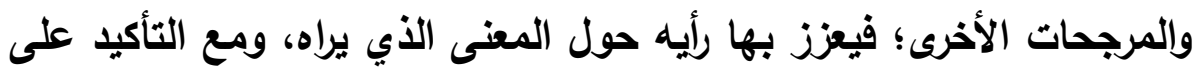

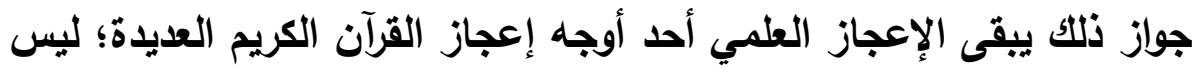

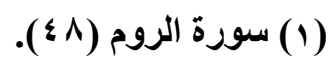

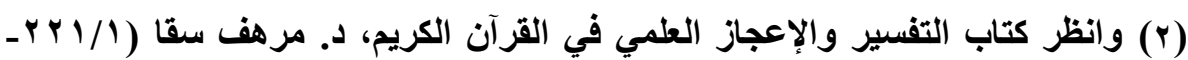
(r) انظر تفصيل ذلك بالأمثلة في بحثي: علاقة العلم التجريبي بمعجزات الأنبياء، منشور

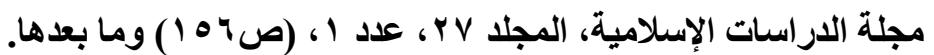

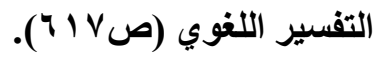

مجلة كلية أصول الدين بأسيوط ،العدد الرابع الثلاثون 14 
د/عبد السلام بن صالح بن سليمان الجار الله

الترجيح بمكتشفات العلم التجريبي في التفسير

هو الوحيد ولا الأقوى، فينبغي أن يأخذ مكانه الطبيعي بين وجوه الإعجاز دون إفراط ولا تفريط.

مجلة كلية أصول الدين بأسيوط ،العدد الرايع الثلاثون 17 . م م 213 


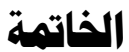

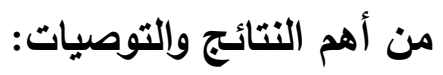

1 - الترجيح بالمكتثفات التجريبية في التفسير يندرج ضمن الأدلة

العقلية الحسية.

r - وظف بعض علماء التفسير المتقدمين المكتشفات التجريبية في

ترجيح بعض معاني الآيات، ويعبرون عنها بالحس والمشاهدة.

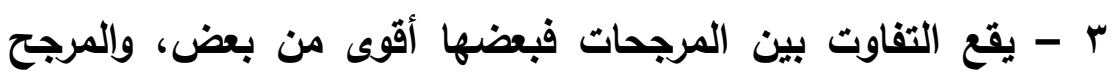

الواحد تتفاوت درجته في الترجيح بحسب ما احتف به من قرائن.

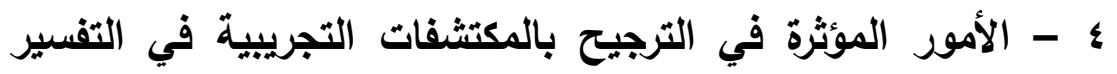

ترجع إلى أمرين: ما يتعلق بالاكتثاف ذاته، وما يتعلق بدلالة الآية عليه.

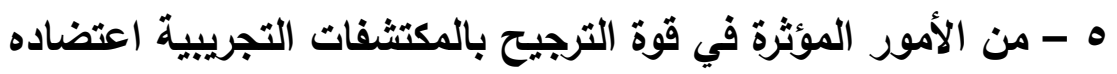

بأدلة أخرى من الكتاب والسنة، أو اللغة، أو أقوال السلف.

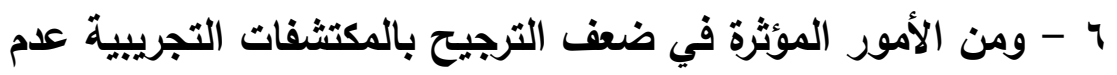

وضوح الاكتشاف أو ضعف الجزم به؛ كونه لا يزال محل النظر والتجرية.

V - ينبغي أن تكون العلاقة بين المفسرين وأصحاب الاكتثافات

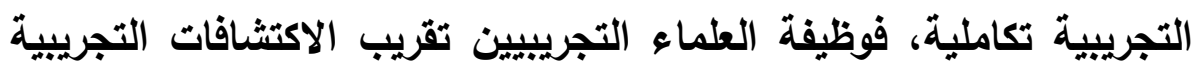
للمفسرين بتوضيحها وشرحها وبيان قوتها من حيث التجرية، ووظيفة

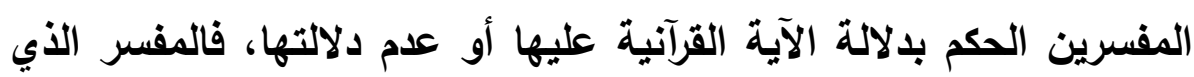

يمتلك أدوات التفسير هو الأقدر على الترجيح في مثل هذه الأمور ('). 1 - ينبفي أن يأخذ الترجيح بالمكتشفات التجريبية مكانه الطبيعي بين المرجحات في التفسير؛ فلا إفراط في الترجيح به عند أدنى دلالة أو علاقةة، بألة

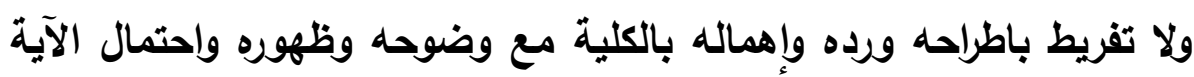

$$
\text { (1) الإعجاز العلمي إلى أين (ص99 ، 9 9-19.9). }
$$

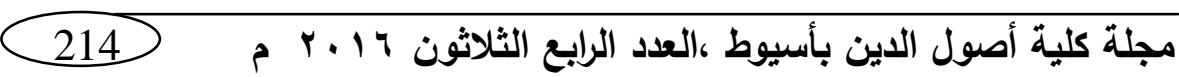


له وسلامته من المعارض.

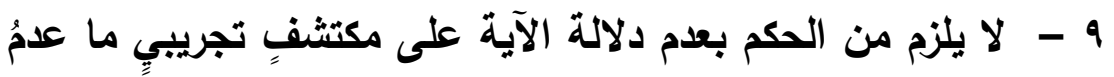

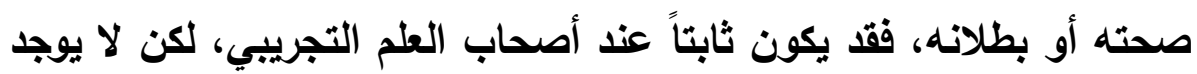

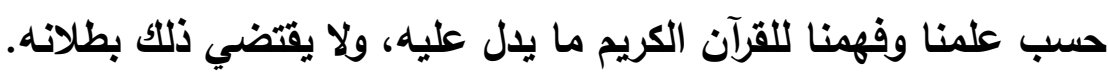




\section{المصادر والمراجع}

1- أثر الاكتثافات العمية في تفسير القرآن الكريم، صالح يحيى

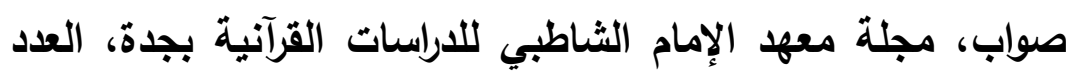

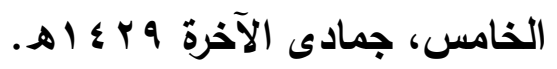

r- الإحكام في أصول الأحكام، لسيف الداين الآمدي، تعليق عبد الرنالق

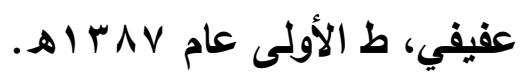

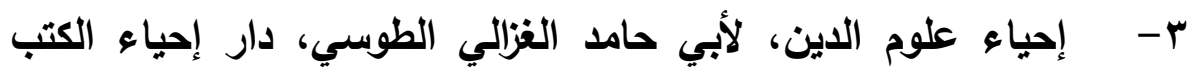

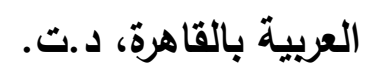

ـ - إرشاد العقل السليم إلى مزايا الكتاب الكريم، لأبي السعود العمادي،

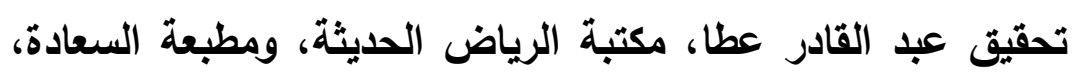

د.ت.

ه- - إرثاد الفحول إلى تحقيق علم الأصول، لأبي عبد الله الثوكاني، دار

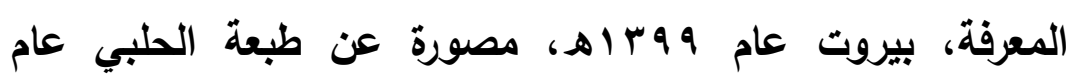
דor

צ- الاستقامة، لابن تيمية، تحقيق محمد رشاد سالم، مكتبة ابن تيمية

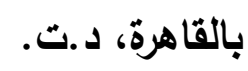

- الاستقراء والمنهج العلمي، محمود زيدان، دار الجامعات المصرية

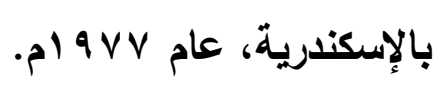

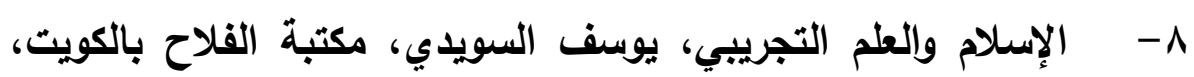

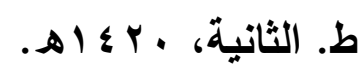
9- - الإعجاز العلمي إلى أين، مساعد الطيار، دار (بن الجوزي بالدمام،

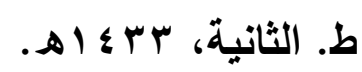
• - - الإعجاز العلمي في القرآن والسنة، محمد بورياب، هيئة الإعجاز 


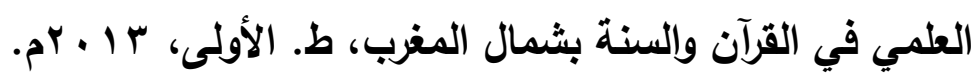

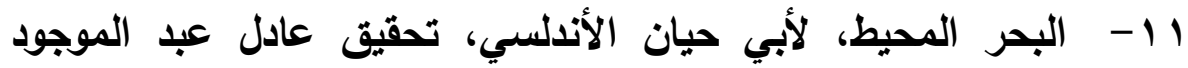

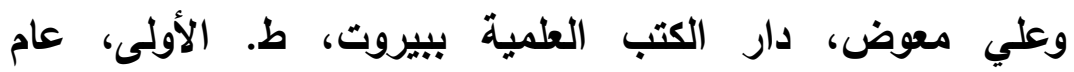

r ا - البحر المحيط في أصول الفقه، لمحمد بن عبد الله الزركثي، تحقيق عبد الستار أبو غدة وعبد القادر العاني، نشر وزارة الأوقاف

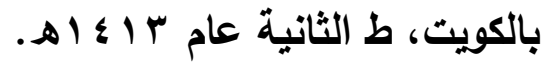

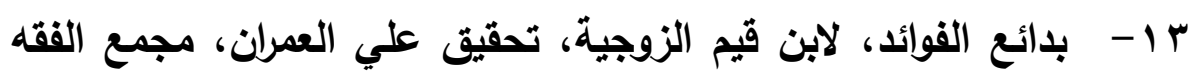

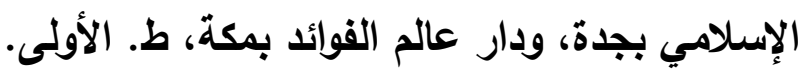
ع ا- - البداية والنهاية، لأبي الفداء بن كثير الامشقي، تحقيق عبد الله بله

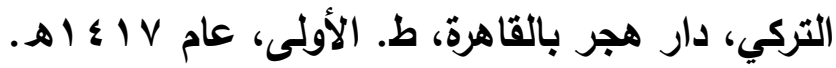

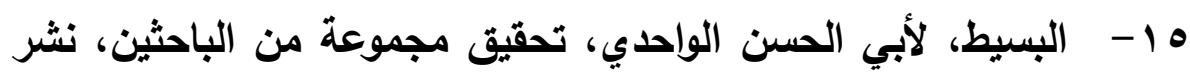

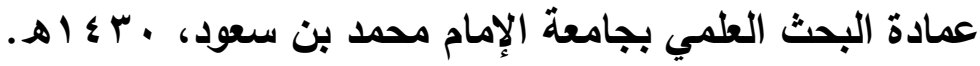
19

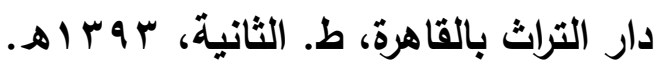
- IV

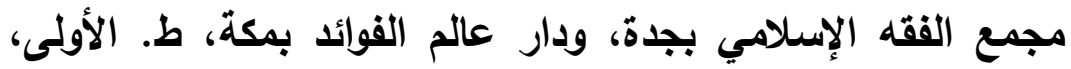

$$
\text { . } 1 \leqslant \text {. } 19
$$

11 - التحرير والتنوير، لمحمد الطاهر بن عاشور، الدار التونسية بتونس،

$$
\text { . } 9 \wedge \text { \& }
$$

19- التفسير بمكتثفات العلم التجريبي بين المؤيدين والمعارض، محمد

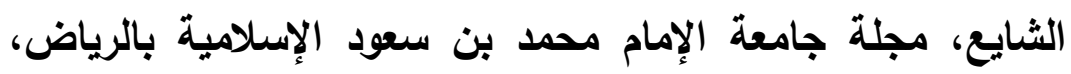

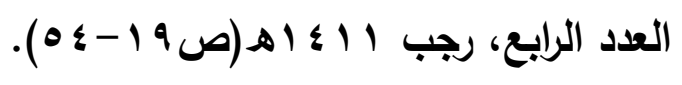

مجلة كلية أصول الدين بأسيوط ،العدد الرابع الثلاثون 19 ب م م 217 
• • - تفسير جزء عم، مساعد الطيار، دار ابن الجوزي بالامام، ط.

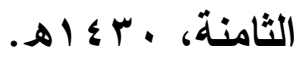

اب- تفسير ابن عرفة الورغمي، تحقيق جلال الأسيوطي، دار الكتب

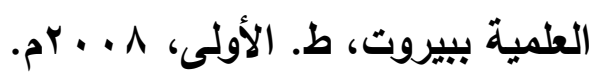

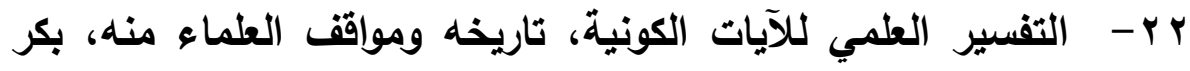

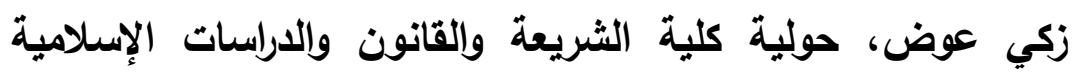

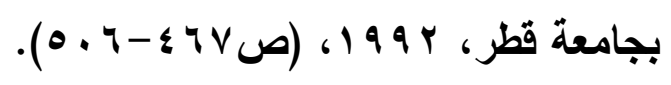

rr- التفسير العلمي للقرآن الكريم بين النظريات والتطبيق، هند شلبي،

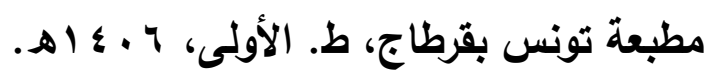

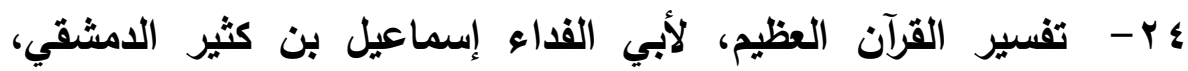

تحقيق عبد العزيز غنيم وآخرين، دار الثعب بالقاهرة، د.ت.

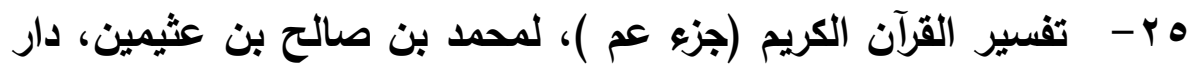

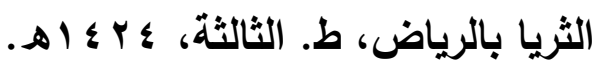

צץ- التفسير والإعجاز العلمي في القرآن الكريم، مرهف سقا، دار محمد

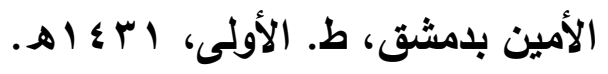

- TV تيسير الكريم الرحمن في تفسير كلام المنان، للسعدي، تحقيق الاوليق

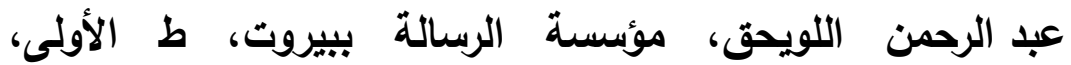

$$
\text { . } 1 \text { ( } 1 \text { r r }
$$

^ץ - جامع البيان عن تأويل آي القرآن، لابن جرير الطبري، دار هجر

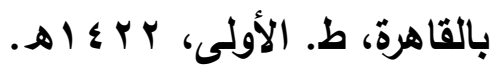

q - - الجامع لأحكام القرآن، لأبي عبد الله القرطبي، دار الثعب بالقاهرة،

$$
\text { د.ت }
$$

• r- الدر المنتور في التفسير بالمأثور، لجلال الدين السيوطي دار 
المعرفة ببيروت، مصورة عن الطبعة الميمنية بمصر عام ؟ اب أهـ.

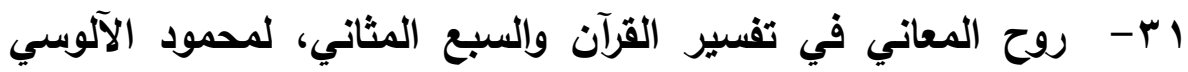
البغدادي، دار إحياء التراث العربي ببيروت، مصورة عن الطبعة

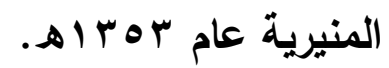
r r ب روضة الناظر وجنة المناظر، لابن قدامة المقدسي، تحقيق د. عبد

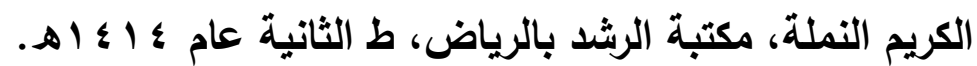

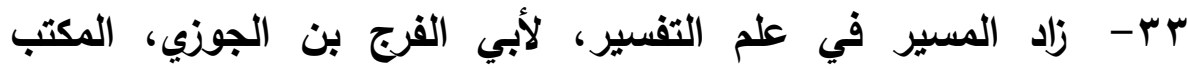

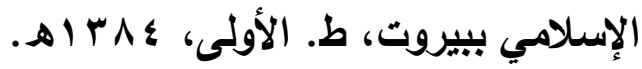

§ ז- سنن سعيد بن منصور، تحقيق سعد الحميد، دار الصميعي

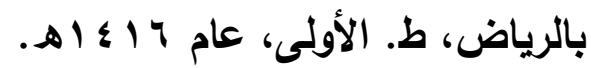
هب- السنن الكبرى، لأحمد بن الحسين البيهقي، نشر داءول دار الفاروق

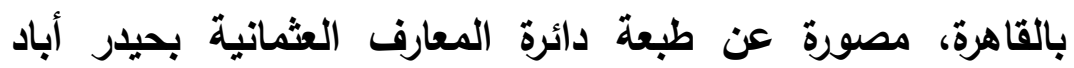

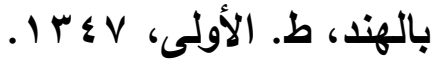

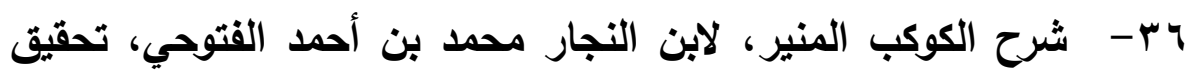

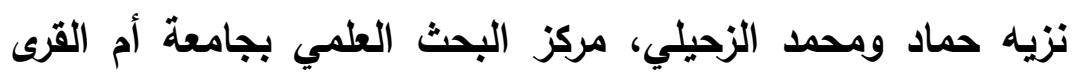

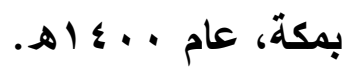

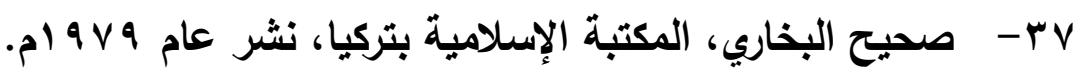

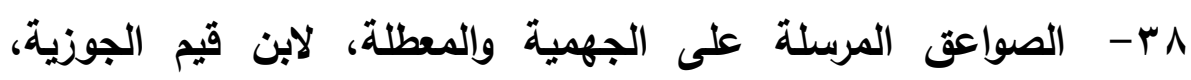

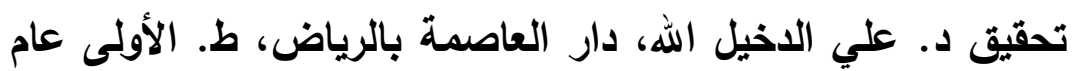

q ب- - الضوابط الثرعية للاكتثافات العلمية الحديثة ودلالتها في القرآن الكريم، رالثد سعيد شهوان، المجلة الأردنية في الاراسات الإسلامية،

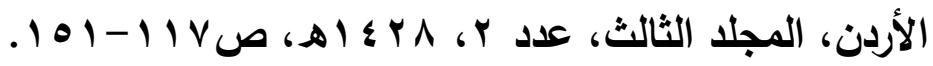


• ـ - علاقة العلم التجريبي بمعززات الأنبياء، عبدالسلام الجارالله، مجلة

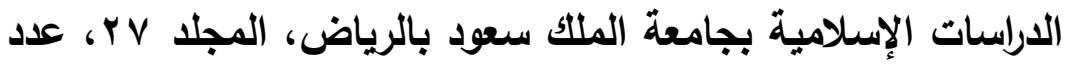

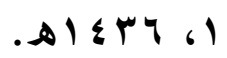

اء - العلوم البيولوجية في خدمة تفسير القرآن الكريم، عبدالحافظ حلمي

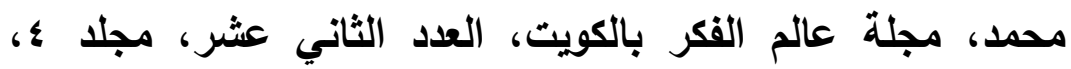
$.0191 r$ ץء - فتح الباري، لابن حجر العقلاني، تحقيق محب الدين الخطيب،

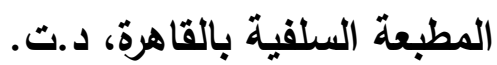

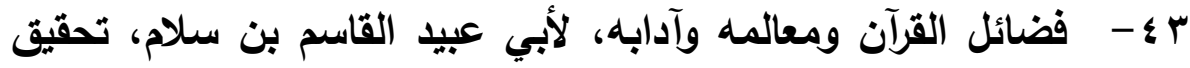

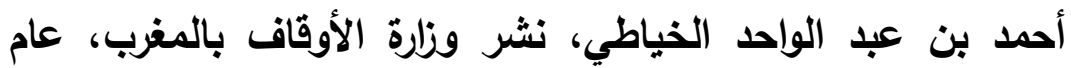
$.8 \leqslant 10$ ؟ ؛ - في ظلال القرآن، لسيد قطب، دار الثروق ببيروت، ط. الأولى عام . $19 \vee r$ 0 ؛ - قواعد الترجيح عند المفسرين، حسين الحربي، دار القاسم بالرياض، ط. الأولى، عام VI إلهـ الهـ ฯ ؛ - الكثاف عن حقائق التنزيل وعيون الأقاويل، لأبي القاسم الزمخثري،

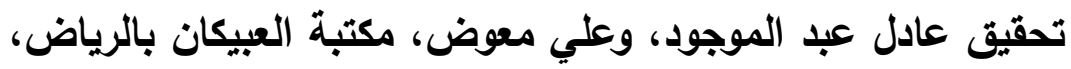

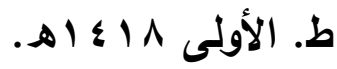
\& V - الكيمياء العامة، المفاهيم الأساسية، ريموند تثانغ، ترجمة فواز

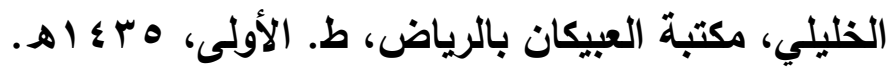

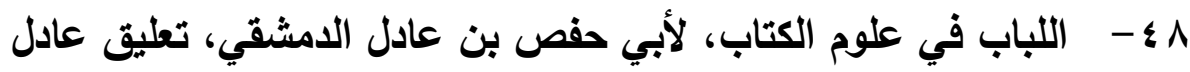

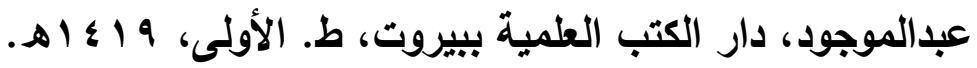
9 ؛ - مباحث في إعجاز القزآن، د. مصطقى مسلم، دار المسلم بالرياض، 


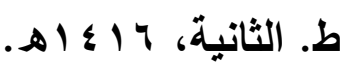

• - - مباحث في علوم القرآن، مناع القطان، مكتبة المعارف بالرياض، ط.

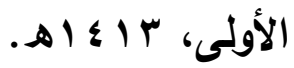

اه- مجموع الفتاوى، لأبي العباس أحمد بن تيمية، جمع عبد الرحمن بن قاسم، مجمع الملك فهد لطباعة المصحف الشريف بالمدينة، عام

ro - المحرر الوجيز في تفسير الكتاب العزيز، لابن عطية الأندلسي، تحقيق الرحالة الفاروق وآخرين، نشر وزارة الأوقاف والشؤون

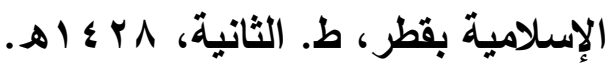

به- مذكرة في أصول الفقه، لمحمد الأمين الثنقيطي، المكتبة السلقية

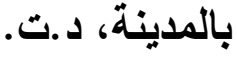

ـ - - المستصفى من علم الأصول، لأبي حامد الغزالي الطوسي، دار إحياء التراث العربي ببيروت، مصورة عن طبعة بولاق بمصر عام

. Dr

هـ- معالم التنزيل، لمحيي السنة الحسين بن مسعود البغوي، تحقيق محمد عبد الله النمر وزميليه، نشر دار طيبة بالرياض عام

$. \$ 1 \leqslant .9$

צه- معاني القرآن، لأبي إسحاق الزجاج، تحقيق عبدالجليل شلبي، عالم

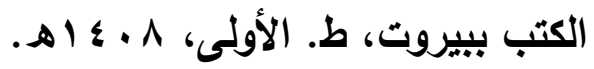
- D - معاني القرآن، ليحيى الفراء، عالم الكتب ببيروت، ط. الثالثة، r ا م أه ^ه - معترك الأقران في إعجاز القرآن، لجلال الدين السيوطي، تحقيق أحمد شمس الدين، دار الكتب العلمية ببيروت، ط. الأولى، 1 ـ ـ أهـ ــ 
الترجيح بمكتثفات العلم التجريبي في التفسير د/عبد السلام بن صالح بن سليمان الجار الله

9ه- المعجم الكبيز، لأبي القاسم الطبراني، تحقيق حمدي عبد المجيد

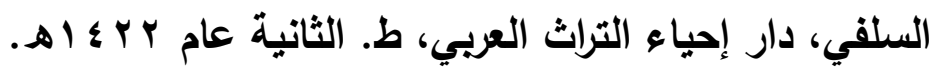

• - - معجم اللغة العربية المعاصرة، أحمد مختار عمر، دار عالم الكتب

بالقاهرة، ط. الأولى، 9 ب ؛ أهـ.

اצ- مناهل العرفان في علوم القرآن، محمد عبد لعظيم الزرقاني، دار

إحياء الكتب العربية بمصر، د.ت.

r - موسوعة الإعجاز العلمي في القرآن الكريم والسنة المطهرة، يوسف

الحاج أحمد، مكتبة ابن حجر بدمشق، ط. الثانية، ع \& ع الهـ.

بף- نظم الارر في تناسب الآيات والسور، لأبي الحسن البقاعي، دائرة

المعارف العثمانية بحيدر آباد، ط. الأولى، و ب أهـ

צ - النكت والعيون، لأبي الحسن الماوردي، مراجعة السيا بن عبد

المقصود، دار الكتب العلمية ببيروت، ومؤسسة الكتب الثقافية

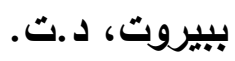

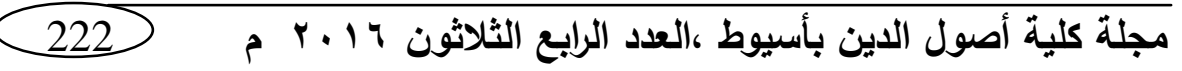

